University of Wollongong

Research Online

Faculty of Arts, Social Sciences and Humanities

- Papers

Faculty of Arts, Social Sciences \& Humanities

$1-1-2020$

Rohingya refugee flooding and changes of the physical and social landscape in Ukhiya, Bangladesh

Mohammad Quader

Hemal Dey

Md Abdul Malak

University of Wollongong, mam716@uowmail.edu.au

Abdul Sajib

Follow this and additional works at: https://ro.uow.edu.au/asshpapers

Research Online is the open access institutional repository for the University of Wollongong. For further information contact the UOW Library: research-pubs@uow.edu.au 


\title{
Rohingya refugee flooding and changes of the physical and social landscape in Ukhiya, Bangladesh
}

\author{
Abstract \\ (C) 2020, Springer Nature B.V. Bangladesh has been dealing with one of the world's largest refugee \\ emergencies along its border with Myanmar (especially in the rough wooded zone of Ukhiya sub-district, \\ Cox's Bazar) due to a massive influx of Rohingya refugees, particularly since 25 August 2017. Resulting \\ high impacts threaten the viability of local plantation as well as natural forests (societal and ecological \\ assets). This research aims to evaluate the impact of the influx on the physical landscape in the Ukhiya \\ sub-district as well as changes of socio-cultural landscape. The study was relied on both geo-spatial and \\ survey data analysis. We argue that Rohingya flooding has a significant impact on changes of physical \\ and socio-cultural landscape of the area in and around Rohingya camps. Results from the normalized \\ difference vegetation index analysis identified that during 2015-2018 the forestry adjacent to the \\ Kutupalong camps (Ukhiya sub-district) declined by $11.23 \mathrm{~km} 2$. Forestry cover fell from approximately \\ $68.9 \%$ of all land to $2.72 \%$; the decline representing about $15.2 \%$ of the entire forested area. Furthermore, \\ the highest elevated area of Kutupalong camps (estimated to be $41 \mathrm{~m}$ ) is likewise affected by \\ anthropogenic activities, for instance, wholesale cutting into the slope, and street and stair construction \\ which is gradually rising the potentiality of landslide and inland flood in several camps. Out of which \\ $27.76 \%$ settlements, $0.35 \%$ and $9.61 \%$ settlements are at risk of landslide and flood, respectively, in the \\ Kutupalong RC and Kutupalong extension campsite. A large proportion of Rohingyas also used wood for \\ fuel; wood used originates from the adjacent forest and is the primary explanation for forestry \\ consumption in Ukhiya sub-district. Its forests and elevation will never return to their original condition if \\ the consumption of forestry assets proceeds unabated. It is argued, that these research findings may \\ inspire locals, national, and global aid agencies to contribute to the introduction of forestry management \\ and environmental protection.

\section{Publication Details} \\ Quader, M., Dey, H., Malak, M. \& Sajib, A. (2020). Rohingya refugee flooding and changes of the physical \\ and social landscape in Ukhiya, Bangladesh. Environment, Development and Sustainability,
}

This journal article is available at Research Online: https://ro.uow.edu.au/asshpapers/282 


\title{
1 Rohingya refugee flooding and changes of physical 2 and social landscape in Ukhiya, Bangladesh
}

\author{
3 Mohammad Abdul Quader $^{1}$ (D) $\cdot$ Hemal Dey $^{1} \cdot$ Md. Abdul Malak $^{1,2} \cdot$ Abdul Majed Sajib $^{3}$ \\ 4 Received: 4 November 2019 / Accepted: 23 May 2020 \\ 5 C Springer Nature B.V. 2020
}

\section{Abstract}

7 Bangladesh has been dealing with one of the world's largest refugee emergencies along its

8 border with Myanmar (especially in the rough wooded zone of Ukhiya subdistrict, Cox's

9 Bazar) due to a massive influx of Rohingya refugees, particularly since 25 August 2017.

10 Resulting high impacts threaten the viability of local plantation as well as natural forests

11 (societal and ecological assets). This research aims to evaluate the impact of the influx on the physical landscape in the Ukhiya sub-district as well as changes of socio-cultural landscape. The study was relied on both geo-spatial and survey data analysis. We argue AQ1 that Rohingya flooding has a significant impact on changes of physical and socio-cultural landscape of the area in and around Rohingya camps. Results from the normalized difference vegetation index analysis identified that during 2015-2018 the forestry adjacent to the Kutupalong camps (Ukhiya sub-district) declined by $11.23 \mathrm{~km}^{2}$. Forestry cover fell from approximately $68.9 \%$ of all land to $2.72 \%$; the decline representing about $15.2 \%$ of mated to be $41 \mathrm{~m}$ ) is likewise affected by anthropogenic activities, for instance, wholesale cutting into the slope, and street and stair construction which is gradually rising the potentiality of landslide and inland flood in several camps. Out of which $27.76 \%$ settlements, $0.35 \%$ and $9.61 \%$ settlements are at risk of landslide and flood, respectively, in the Kutupalong RC and Kutupalnog extension campsite. A large proportion of Rohingyas also used wood for fuel; wood used originates from the and is the primary explanation for forestry consumption in Ukhiya sub-district. Its forests and elevation will never return to their original condition if the consumption of forestry assets proceeds unabated. It is argued, that these research findings may inspire locals, national, and global aid agencies to contribute to the introduction of forestry management and environmental protection. mquader@vub.be 


\section{Introduction}

The Rohingya people, an ethnic majority Muslim group who for centuries had resided in the Rakhine territory of Myanmar, have sought refuge in Bangladesh following worsening persecution in a country increasingly dominated by the army-backed government (Hassan et al. 2018). Rohingya asylum seekers/refugees have fled to Bangladesh from Myanmar since the 1970s (Amnesty International 2016), but their numbers have risen steeply since the Myanmar government effectively deprived them of the possibility of citizenship in the 1980s (as onerous requirements to do so were impossible to meet), declaring them to be resident foreigners (often describing them as illegal 'Bengali' migrants even though a family may have been there for generations), and rendering them stateless persons (Milton et al. 2017). This status denies them secondary and higher education, restricts their movements (with permits required to travel); they are prohibited from holding public office nor are they eligible for employment in the civil service. Sexual and reproductive rights were also compromised (with forced terminations reported in some areas). Their religious activities are also restricted in Myanmar with Rohingya often unable to gain permission to perform the hajj, one of the five 'pillars of Islam'. In the late 1980s, the land was also confiscated without compensation, rendering Rohingyas "homeless" [as well as] "stateless"” (Milton et al. 2017). From 1992 onwards, Bangladesh categorized Rohingyas as 'asylum seekers' rather than refugees. Encouraged to return to Myanmar, those who did so found little had altered and many attempted to return to Bangladesh. In 2016-2017 following the persecution on Rohingyas rise dramatically, including a massacre in which hundreds died, women and girls were sexually assaulted. Moreover, thousands of dwellings were burned to the ground and they were forced to flee to Bangladesh (Sohel 2017; Milton et al. 2017).

The present condition of the Teknaf promontory and the adjoining Ukhiya sub-district of Cox's Bazar (areas to which the vast majority of Rohingyas fled and are now housed in and around two refugee camps) was produced by both deforestation and attempts at subsequent afforestation. Slope cutting, ordinarily used for filling in low lying regions, occurred throughout the 'ecologically critical' Teknaf promontory (Imtiaz 2018) since the mid1970s. The increasing weight of population, including the sudden deluge of about 240,000 Rohingya from Myanmar in the mid-1970s and a similar figure again in the mid-1990s as well as later influxes, has seen the forested areas constantly utilized (and thus transformed) for human settlement purposes and for agrarian uses (UNDP Bangladesh and UN Women Bangladesh 2018). During the 1990s huge quantities of trees were felled to build temporary shelters. The uprooted Rohingya populace sourced fuel and other materials from the nearby natural forests, consequently denuding the steep slopes that characterize the area and creating an increased risk of landslides. Most of the slopes above the settlements consequently suffered extensive deforestation (primarily for fuel) and the terrain itself was altered by slope cutting for housing, roads, and steps. Later, after the migrant population's initial makeshift housing attempts, the authorities chose to move displaced Rohingya to camps (GFDRR 2018). It is to the area of these camps that 720,000 Rohingya evacuees have fled from Myanmar since August 2017 as a result of fierce persecution by Myanmar military, police, and local militias, further burdening the already over-crowded settlement camps in Ukhiya (Milton et al. 2017).

The large number of Rohingyas moving to the woodland regions in the Ukhiya subdistrict posed a serious risk to forests, both natural and plantation (Imtiaz 2018) as well as to social forestry (UNDP Bangladesh and UN WOMEN Bangladesh 2018). The resulting impacts of the influx on the Ukhiya sub-district environment affect both the uprooted 
Rohingya populace and host networks, and ecological impacts have become a vital key area of concern (GFDRR 2018). Between December 2016 and December 2017, the area of the Kutupalong-Balukhali settlement camp (the largest in Bangladesh, and now the most populous worldwide (UNHCR 2019) extended from 146 hectares to 1365 hectares (an increase of 835\%) (Hassan et al. 2018). Before the 2017 influx, Rohingyas had encroached upon more than 695 acres of Forest Department land around Cox's Bazar (Hussain 2018). A further 4300 acres (approx. 2000 hectares) of slopes were later levelled and forestry removed in the creation of temporary shelters, offices, and paths for Rohingya people in Ukhiya and Teknaf sub-districts of Cox's Bazar. They also accessed forestry for fuel (which was not otherwise supplied to the displaced population). These activities threaten the biodiversity of environmentally threatened areas. (See UNDP Bangladesh and UN WOMEN Bangladesh 2018; Hussain 2018; The Daily Star 2018).

A remote detecting examination, RIVNA (Rapid Impact, Vulnerability, and Need Assessment), found that of roughly 18,780 hectares, 2687 hectares were lost in a single year since March 2017 (GFDRR 2018). According to the Martin (2017), each Rohingya family utilizes an average of 60 bamboo culms (stems) (weighing approx. $360 \mathrm{~kg}$ ) to build their temporary shelters, while on average 6800 tons of fuelwood is being collected every month (about $150 \mathrm{~kg}$ per family). Although most are purchased at the market, it is sourced from nearby forests. With demand already exceeding sustainable supply prior to the 2017 influx, the situation worsened substantially (UNDP Bangladesh and UN WOMEN Bangladesh 2018). Officially, over 2000 hectares of forests have been destroyed due to camp development after the entry of more than 750,000 Rohingyas since August 2017. The value of the 2500 hectares of deforested land 'lost' to the Rohingya camps equals BDT 741.31 crore or $\$ 86.67$ million (The Dhaka Tribune 2018). This immense population influx causes an estimated loss of 40 million BDT every year in Bangladesh. In addition, the loss of vegetation on about 573 hectares has adverse impacts on climate mitigation as it represents an absolute loss of 24,678.35 tons of carbon sequestration every year (Labib et al. 2018). Refugee influx additionally threatens ecosystems (due to pollution, severe drawdown on subterranean water supplies, habitat loss), and the survival of the wild creatures of forest due to habitat loss and fragmentation. That the camps are constructed in areas that were the natural habitat of the Asian elephant has meant a clash where human and animal lives may be lost. As well as housing and other construction destroyed when elephants come into the camps in search of food. This is their natural movement but serious human-elephant clashes that resulted in the death of a number of displaced people close to camps created dread among refugees (Rahman 2019). Growing concern has resulted in the development of sanctuary for them to accommodate the elephants (Honeth et al. 2017).

The indiscriminate slope cutting and deforestation have been causing other ecological damage, including destabilized slopes, soil erosion, for example, gulling and riling, and increased downstream siltation (Hassan et al. 2015). The presence of forestry (natural and plantation, and including hardwood, softwood, understory, and bamboo, as well as coastal mangrove) is significant in providing a supportive network for soils, helping soils (and thus people) survive and allow residents to pursue their livelihoods (e.g. fishing, agriculture). Hence the present level of deforestation is exceedingly hazardous for both hilly areas and for the coastal areas as it is increasing residents' exposure to climate change impacts while decreasing community resilience and adaptive capacity (Fedele et al. 2016). Hence, given the level of concern regarding all of these circumstances, the present research was conducted to assess the impact of Rohingya refugee influx on loss of vegetation cover in Ukhiya sub-district, by conducting a quantitative evaluation of forest cover change in Ukhiya sub-district utilizing an NDVI (normalized difference vegetation index) analysis and 
questionnaire survey. Therefore, the findings of this study will play a significant role to demonstrate the drastic effect of Rohingya settlement on forest cover. In addition, it may help the authority to take potential measures against upcoming flood and landslides vulnerability. Moreover, this research may encourage forest management authority, local government and international authority to mitigate the impact by crafting a sustainable forest management plan, afforestation, and resettlement program.

\section{Material and methods}

\subsection{Study area}

The study area Ukhiya sub-district is in the Cox's Bazar district in Chattogram Division, Bangladesh (Fig. 1). It is bounded by Ramu sub-district to the north, Teknaf sub-district to the south, Arakan state of Myanmar, and Naikhongchhari (Bangladesh) sub-district to the east, and the Bay of Bengal to the west. Ukhiya has 5 Unions, 13 Mauzas/Mahallas, and 54 villages. Ukhiya sub-district occupies a total area of $261.8 \mathrm{~km}^{2}$, and in 2013 (before the massive 2016-2017 influx) the Bangladesh Bureau of Statistics identified a population comprising 19,189 households (BBS 2013). According to the 2011 census, the total population numbered 207,379. By 2018, the total number of displaced Rohingya in Bangladesh was 884,000 with about $87 \%$ of them living in the study area (GFDRR 2018).

\subsection{Data source, gathering, and analysis}

This research was conducted based on geospatial data and first-hand accounts from the field. Figure 2 represents the process of data gathering, analysis, and presentation for both primary and secondary data. For geospatial analysis, Landsat-8 OLI/TIRS (Operational Land Imager (OLI)/Thermal Infra-Red Scanner (TIRS)] multispectral satellite images, UAV [Unmanned aerial vehicles) imageries and contour lines of Kutupalong mega camp area (Table 1) were used [data are collected from the United States Geological Survey (USGS) Global Visualization Viewer, and Humanitarian Data Exchange (HDX) website, respectively]. The main purpose of using geospatial data is to conduct NDVI (normalized difference vegetation index), the assessment of the risk of settlements to natural hazards and to provide data regarding forest depletion and changes of physiography. It is difficult to access cloud-free images of the area because of climatic monsoon trend which exist between March to November (Hassan et al. 2018); however, we have used maximum cloudfree images for the both year that which is $0.21 \%$ (March 2015) and $0.34 \%$ (April 2018), respectively (Table 1). Landsat-8, UAV imageries, and contour lines have $30 \mathrm{~m}, 10 \mathrm{~cm}$ and $1 \mathrm{~m}$ spatial resolution, respectively. The contour lines were developed in December 2017 from UAV (unmanned aerial vehicle) technology by Needs and Population Monitoring (NPM) team of IOM (International Organization of Migration) (HDX 2020a). In addition to that, for first-hand data, a structures open and close ended questionnaire was used. The participants were chosen for the questionnaire survey through random sampling from the Kutupalong refugee camp in Ukhiya sub-district. This survey method helped to validate the geo-spatial data as well as provided valuable insights regarding the human dimension on the physical environment. The following subsections describe both of the methods in detail. 


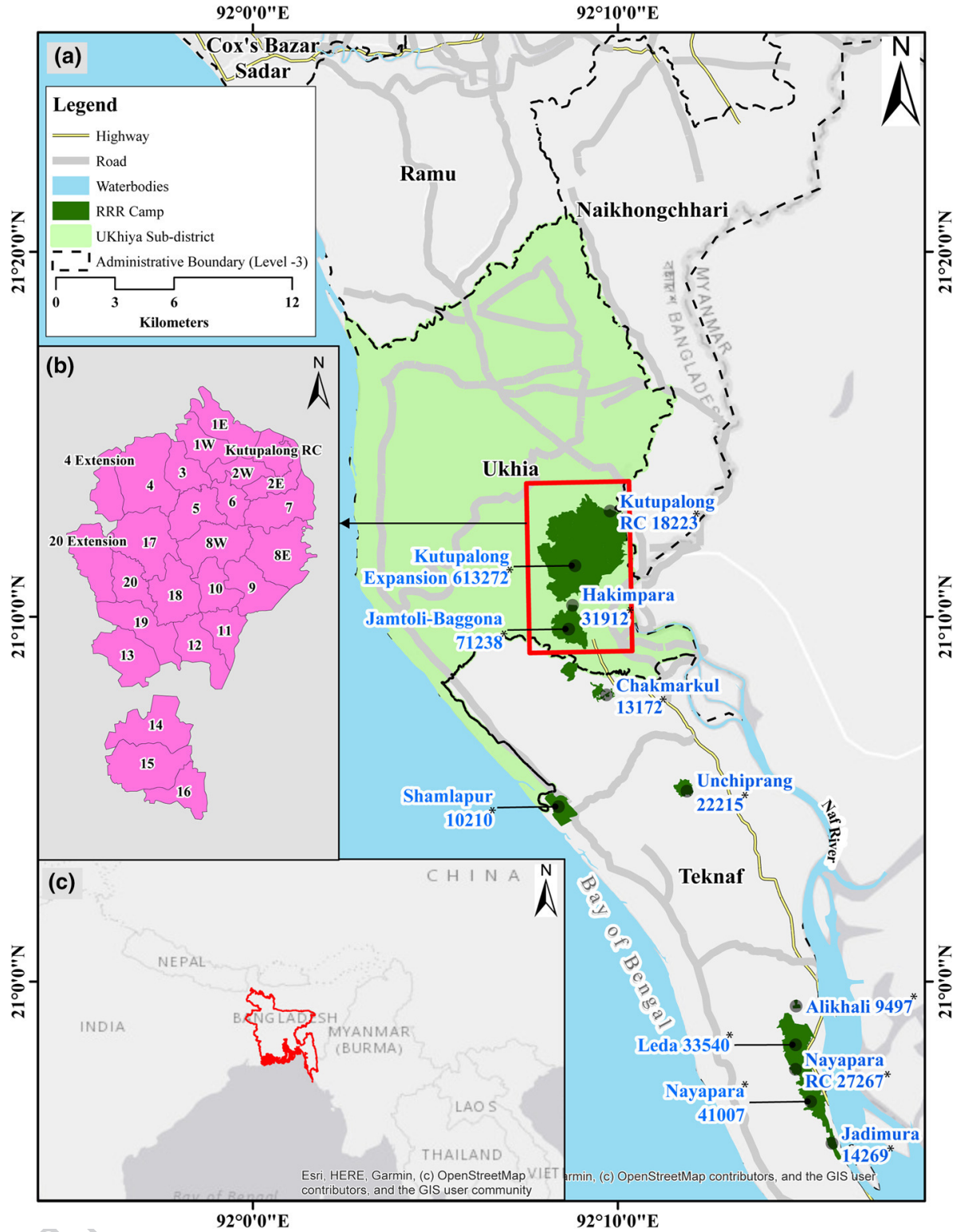

Fig. 1 The map (a) showing the location of Ukhiya sub-district and refugee camps with the population. * = Population, $\mathrm{RC}=$ refugee camp; (b) The inset map represents the Kutupalong expansion site with the camp number. (c) The inset map shows the location of Bangladesh (denotes in red colour) with three sides; west, north, and east, bordered by India, south bordered by the Bay of Bengal and only a small border with Myanmar in the southeast where the study area, Ukhiya sub-district, is located 
M. A. Quader et al.

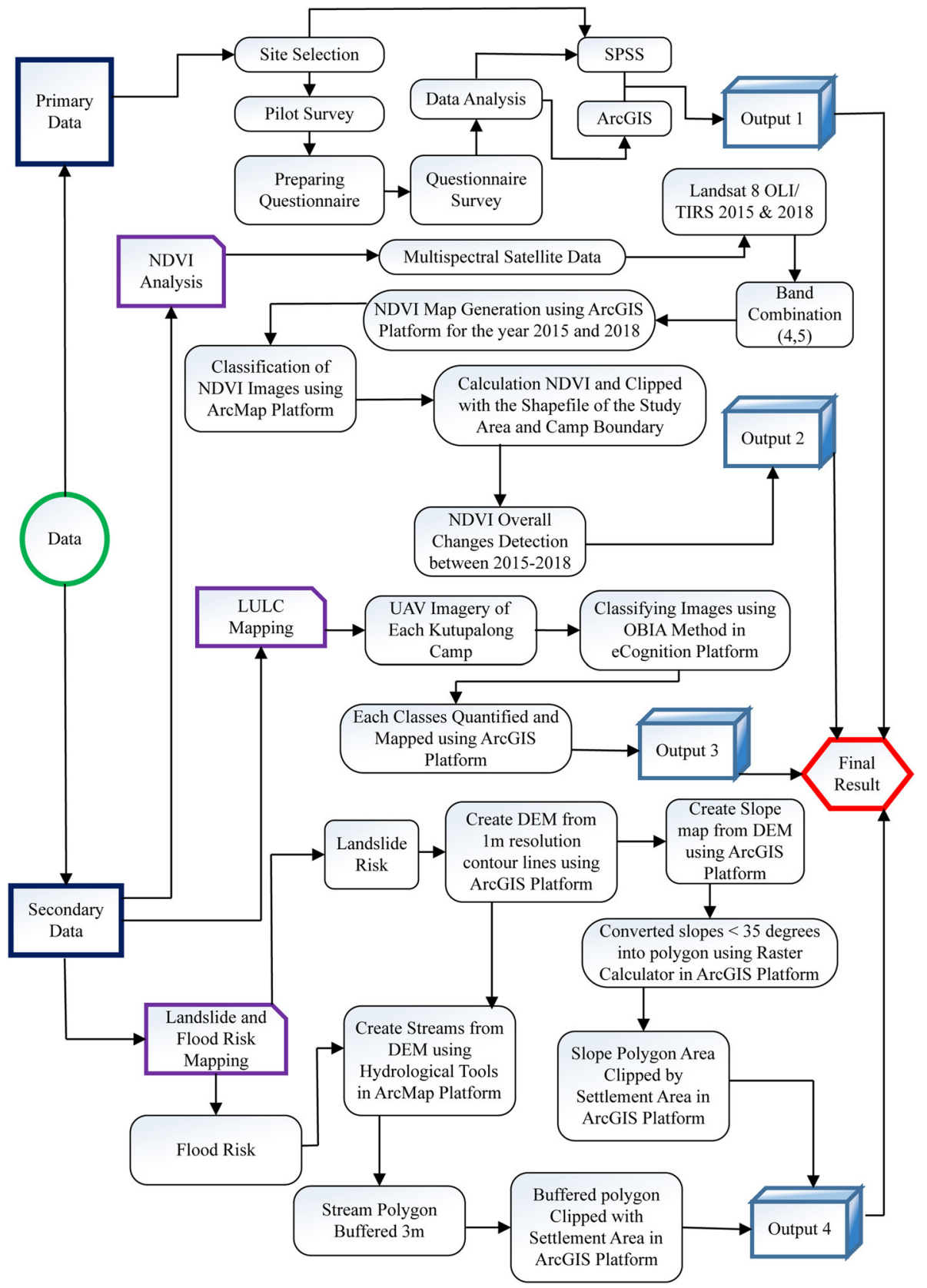

Fig. 2 Workflow of primary and secondary data processing. NDVI=normalized difference vegetation index, OLI = operational land imager, TIRS = thermal infrared sensor, LULC $=$ land use and land cover, $\mathrm{UAV}=$ unmanned aerial vehicle, $\mathrm{OBIA}=$ object-based image analysis, $\mathrm{DEM}=$ digital elevation model 
Rohingya refugee flooding and changes of physical and social...

Table 1 Data sources of satellite images. Satellite images has been downloaded free from USGS global visualization viewer and humanitarian data exchange websites

\begin{tabular}{|c|c|c|c|c|c|}
\hline Data types & Acquisition Date & Resolution & Row/path & Cloud cover & Source \\
\hline Landsat 8 OLI/TIRS & 03/04/2018 & $30 \mathrm{~m}$ & $136 / 45$ & 0.21 & $\begin{array}{l}\text { United States Geological } \\
\text { Survey (USGS) Global } \\
\text { Visualization Viewer } \\
\text { https://glovis.usgs.gov/app }\end{array}$ \\
\hline Landsat 8 OLI/TIRS & $29 / 04 / 2016$ & $30 \mathrm{~m}$ & $136 / 45$ & .34 & $\begin{array}{l}\text { United States Geological } \\
\text { Survey (USGS) Global } \\
\text { Visualization Viewer } \\
\text { https://glovis.usgs.gov/app }\end{array}$ \\
\hline UAV Imagery & $24 / 06 / 2019$ & $10 \mathrm{~cm}$ & & & $\begin{array}{l}\text { Humanitarian Data } \\
\text { Exchange (HDX) } \\
\text { https://data.humdata.org/ }\end{array}$ \\
\hline Contour Lines & December 2017 & $1 \mathrm{~m}$ & & & $\begin{array}{l}\text { Humanitarian Data } \\
\text { Exchange (HDX) } \\
\text { https://data.humdata.org/ }\end{array}$ \\
\hline
\end{tabular}

\subsubsection{Data collection and processing for geo-spatial analysis}

Raw satellite images were processed through GIS and remote sensing-based software (image pre-processing, NDVI generation, LULC classification, analysis and mapping). The LULC (Land use land cover) map of 26 Rohingya refugee camps of kutupalong area was prepared using drone imageries. The drone images were captured by the NPM (Needs and Population Monitoring) program of IOM Bangladesh. NPM is a part of the IOM's global Displacement Tracking Matrix (DTM) programming. The function of DTM programming is to manage the system for tracking and monitoring population displacement during crises (HDX 2020b). For image classification, we applied an object-based image analysis (OBIA) method through eCognition Developer 9.0 geospatial software. OBIA is a very time-consuming method for image classification and a combined output of supervised and unsupervised technique (Ahmed et al. 2020). The output of the image classification of each camp was later merged together and computed in the ArcMap version 10.7 platform based on each class.

In order to assess the impact on vegetation cover, before influx and after the most recent (2016-2017) influx of Rohingya refugees, we used NDVI (Normalized Difference Vegetation Index) analysis. The NDVI analysis allows vegetation monitoring of different years from multispectral satellite images (Gandhi et al. 2015). The NDVI index value varies between -1 and 1 . Values close to 1 represents dense vegetation. For sparse vegetation NDVI values lie between 0.2 and 0.4 , for moderate dense vegetation and dense vegetation NDVI values range from 0.2 to 0.4 and from 0.6 to 1, respectively (Alex et al. 2017; Quader et al. 2017). Two multispectral images of March 2015 and April 2018 were used, respectively. NDVI analysis (Eq. 1) was applied to detect the areas of vegetation cover change. NDVI uses the NIR (Near Infrared) and Red bands for creating the ratio. NIR and Red which is represented by band 5 and band 4, respectively, in Landsat-8 OLI/TIRS images are used to calculate NDVI values. For calculations of NDVI, the following formula (Eq. 2) has been used in this study.

$$
\mathrm{NDVI}=(\mathrm{NIR}-\mathrm{RED}) /(\mathrm{NIR}+\mathrm{RED})
$$

In case of Landsat-8 OLI/TIRS multispectral satellite images the equation for NDVI turns in the following form (Eq. 2). 


$$
\text { NDVI }=(\text { Band } 5-\text { Band } 4) /(\text { Band } 5+\text { Band } 4)
$$

After calculation NDVI, the classified images were clipped with the shapefile of the study area and camp boundary separately. Thereafter subset images were classified using ArcMap version 10.7. NDVI values of the Ukhiya and area inside camp boundary is classified based on index value ranges from -1 to 0.19 as Non-Vegetation (Water, sand, barren land, and settlements) area and 0.2 to 0.54 as vegetation area, respectively, (Fig. 5) and area of each attribute is quantified.

The maps of settlements that are at risk to landslide and flood at the kutupalong refugee camp area were prepared using a mixed-method. The mixed-method was developed by a combined study of IOM (International Organization for Migration)-UNHCR (United Nations High Commissioner for Refugees)-ADPC (Asian Disaster Preparedness Center). The landslide risk map was established based on potential failure slopes above $35^{\circ}$ (Humanitarian Response 2018) and the slope area ranges from $0^{\circ}$ to $51.12^{\circ} \mathrm{s}$ in the kutupalong camp area (Fig. 3b). The slope was developed from DEM (Digital Elevation Model). We used $1 \mathrm{~m}$ contour lines of 2017 from HDX to create the DEM (Fig. 3a). The DEM height of the study ranges between 41 and $2 \mathrm{~m}$. Finally, the slope area more than 35 degrees was clipped with the settlement area for mapping and calculating the area of each camp at risk to a landslide. We used hydrological tools in ArcMap version 10.7 to create stream polygons from DEM. The stream is buffered to $3 \mathrm{~m}$ to create a flood layer of the

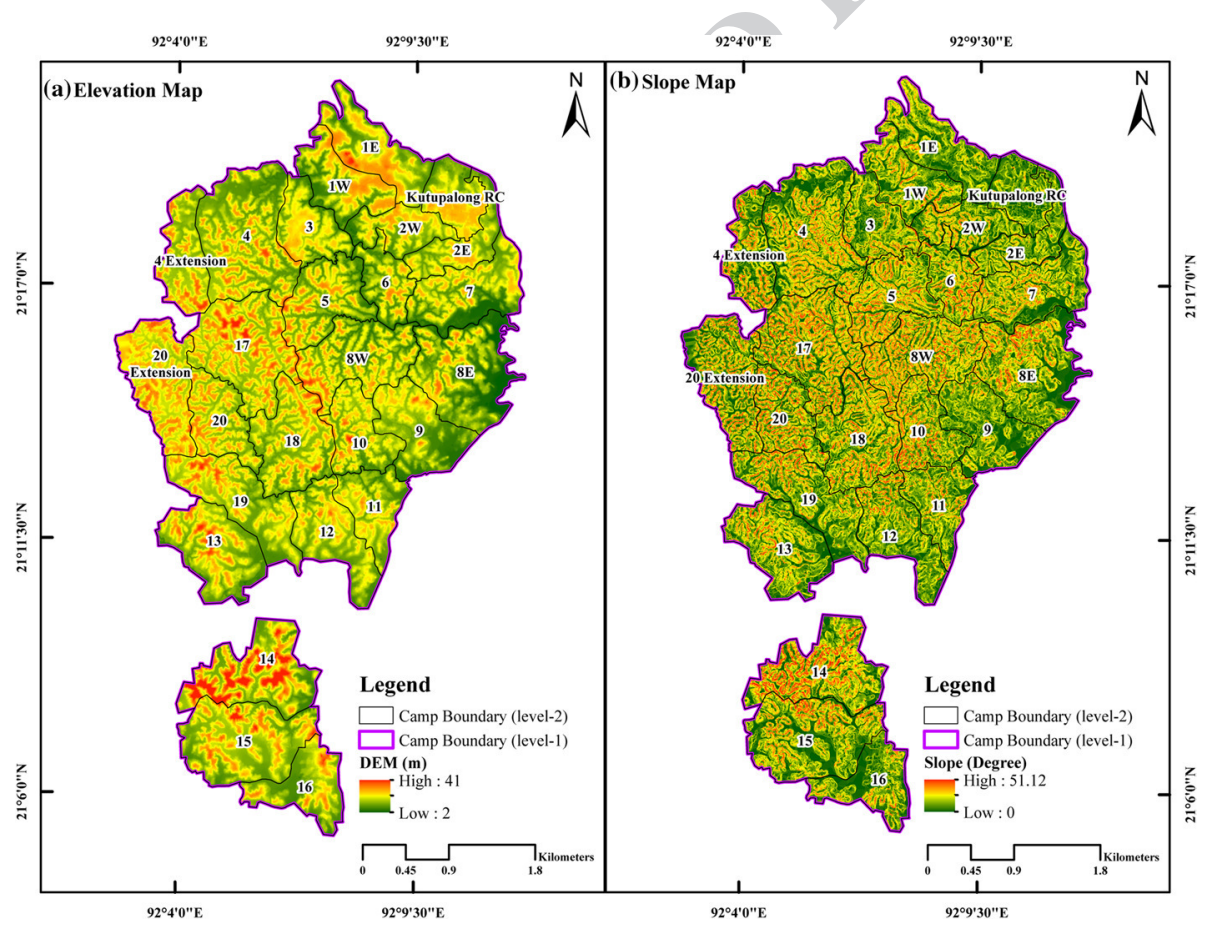

Fig. 3 DEM and slope map output from contour lines a the elevation map (DEM) of Kutupalong camp. The red colour denotes the highest elevation $(41 \mathrm{~m})$ and green denotes the lowest elevation $(2 \mathrm{~m})$; $\mathbf{b}$ the slope map of the Kutupalong camp. The red colour represents the highest slope value $\left(51.12^{\circ}\right)$ and the green represents the lowest slope value $\left(0^{\circ}\right)$ 
Kutupalong camp. These were tested on-site and modified where appropriate to represent a more realistic flooding scenario (Humanitarian Response 2018). Later the buffer streams were masked with the settlement of kutupalong for each camp for mapping and calculation of the settlements at flood risk.

\subsubsection{Participants selection, data collection, and analysis of questionnaire survey data}

A face to face interview was conducted to collect the survey data through a structured questionnaire. Because of the cross-cultural intention of this research project to engage Rohingya participants for whom the first language was not either English or Bengali, reliable translation was imperative. As a consequence, during the conducting of fieldwork, four experienced interpreter were employed to help the enumerator conducting the survey questionnaire with Rohingya people. Although there are numerous approaches to determine sample size, following Daniel and Cross (2018) and considering the Rohingya population in the site with a 95\% confidence level and 5\% precision level a total of 350 Rohingya adults were interviewed from 17 blocks of Kutupalong camp in Ukhiya, Bangladesh. Random sampling was used to select the participants and gender was not taking into account regarding this. The interviewed participants from each block were not similar because of unequal population distribution.

The questionnaire was designed and divided into two main sections. The first section includes the socio-demographic information of the participants. Second section aimed to know how Rohingya refugees are connected with the physical environment in terms of housing, resource collection, and other livelihood means that have an adverse impact on the physical and social environment. Before going to the final survey, the questionnaire was pilot tested with 15 participants to ensure the relevancy of the information gathered and avoid any redundancy. The survey was conducted between 13 August 2018 and 27 August 2018. After the collection of survey data from the field, SPSS version 24 was used to enter and analyse the data. The quantitative data is presented as tabular and graphical format.

\section{Results}

This section aims to present the findings derived from the satellite image processing and analysis of the questionnaire survey. In terms of the socio-demographic status of participants (see Table 2), the result shows, among 350 participants $82.6 \%$ were male and $17.4 \%$ were female. There were no participants aged below 18. The largest group of respondents (33.1\%) were from 28 to 37 age groups and $25.1 \%$ of respondents were between 18 and 27 age groups. Although the maximum of respondents were young, 14.5\% of respondents were above 57 years old. In terms of marital status $84.9 \%$ were married, $12.3 \%$ were unmarried and the rest of them were widowed. A large portion of the participants could not be able to complete primary education (percentage of illiterate is $30.4 \%$ ) while only $17.9 \%$ could finish secondary level education. A remarkable number of participants (12.5\%) went to madrasah (religious school) for education. Occupations of the respondents changed vastly due to migration. Maximum of them were farmer, fisherman, and businessman before migration (percentages are 37.8, 10.5, and 14.2, respectively) and became jobless after influx. Almost 54.3\% of them were found unemployed in Rohingya camp. Some of them got involved in a daily wage basis job (12.2\%) and shopkeepers $(13.1 \%)$ inside the camp. They had an average $8.73 \mathrm{kani}$ (a local unit of measurement of land where 
Table 2 Socio-demographic characteristics of Rohingya respondents. Data is based on the participant's answer

\begin{tabular}{|c|c|c|c|c|}
\hline \multirow{2}{*}{$\begin{array}{l}\text { Characteristics } \\
\text { Age }\end{array}$} & \multicolumn{2}{|c|}{ Percentage (\%) } & \multirow{2}{*}{$\begin{array}{l}\text { Characteristics } \\
\text { Gender }\end{array}$} & \multirow[t]{2}{*}{ Percentage $(\%)$} \\
\hline & & & & \\
\hline $18-27$ & 25.1 & & Male & 82.6 \\
\hline $28-37$ & 33.1 & & Female & 17.4 \\
\hline $37-47$ & 18.2 & & Marital status & \\
\hline $47-57$ & 9.1 & & Married & 84.9 \\
\hline $57+$ & 14.5 & & Unmarried & 12.3 \\
\hline Occupation & Previous & Present & Widow & 2.8 \\
\hline Farmer & 37.8 & 1.1 & Literacy rate & \\
\hline Fisherman & 10.5 & 0.3 & Illiterate & 30.4 \\
\hline Businessman & 14.2 & 3.4 & Primary & 34.9 \\
\hline Barber & 0.8 & 1.1 & Secondary & 179 \\
\hline Shopkeeper & 9.4 & 13.1 & Higher secondary & 2.6 \\
\hline Day labor & 6.5 & 12.2 & Graduation degre & 1.7 \\
\hline Job Holder (NGO) & 4.8 & 6.8 & Madrasah & 12.5 \\
\hline Housewife & 5.4 & 6.6 & Religion & \\
\hline Student & 5.4 & 1.1 & Hindu & 0.6 \\
\hline Unemployed & 5.2 & 54.3 & Muslim & 99.4 \\
\hline
\end{tabular}

$1 \mathrm{kani}=120$ decimal) land in Myanmar and about 94,6\% of respondents had their own house to live over there.

The core findings are divided into several parts. The first section of the results draws from satellite image processing to detect the changes regarding forest cover and compares the changes before and after the Rohingya influx. The second section illustrates the core findings from face to face interviews to examine how Rohingya people are responsible to reduce the forest resources. The third section examines how Rohingya people and their settlement accelerate the depletion of ecosystem services, and degrade surrounding social, economic, and cultural landscape. The final section discusses the impact of cutting land due to Rohingya settlement on the increases the flood and landslide risk..

\subsection{Refugee resettlement, LULC, changes in elevation and forest cover}

The 2019 LULC mapping represent by six broad class namely-agricultural land, barren land, settlements, vegetation, water bodies, and others (Fig. 4). There was 5.17\% agricultural land, 58.22\% barren land (barren land include camp roads, hilly area, playgrounds, and grassland) $27.76 \%$ settlements, $7.74 \%$ vegetation, $1.05 \%$ waterbodies and $0.06 \%$ other (e.g. main roads) of total land were found in the Kutupalong RC and Kutupalnog extension camp area (Table 3 ).

In terms of agricultural land, camp 08E, 12, 15, and 16 have more than 10\%, Camp 01E, 01W, 02E, 02W, 07, 09, 11, 14 and 19 have more than 5\% and Camp 03, 04, 13 and Kutupalnog RC have less than 5\% arable land, respectively. Camp 02W occupies the highest settlement area which is $51.02 \%$ and Camp 20 extension has the lowest (7.44\%) settlement area. Only 4 camps $(01 \mathrm{E}, 01 \mathrm{~W}, 12$, and Kutupalong RC) have more 


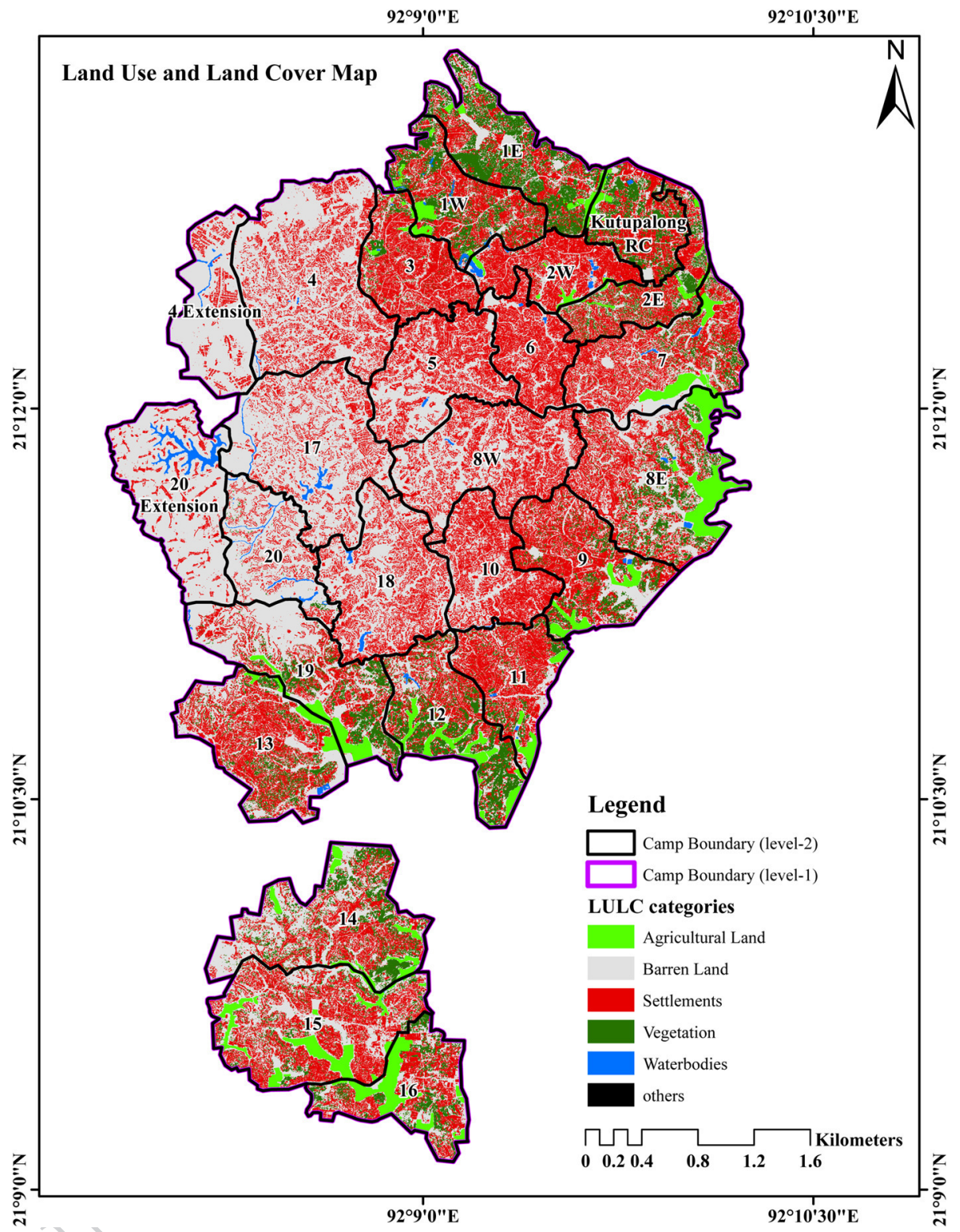

Fig. 4 Land use and land cover (LULC) map of 2019 in the Kutupalong campsite. The light green, grey, red, dark green, blue, and black colour represent the agricultural land, barren land, settlements, vegetation, water bodies, and others, respectively

than $20 \%$ vegetation coverage. Camp 04 and 20 extension has the highest percentage of barren land $(89.76 \%$ and $87.50 \%$, respectively) it is because both of the camps are newly developed. The area percentage of water bodies in kutupalong camps are very low, however in rainy season flash flood occurs in this region due to its hilly structure 286 (Chowdhury and Hossain 2015). 
M. A. Quader et al.

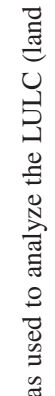

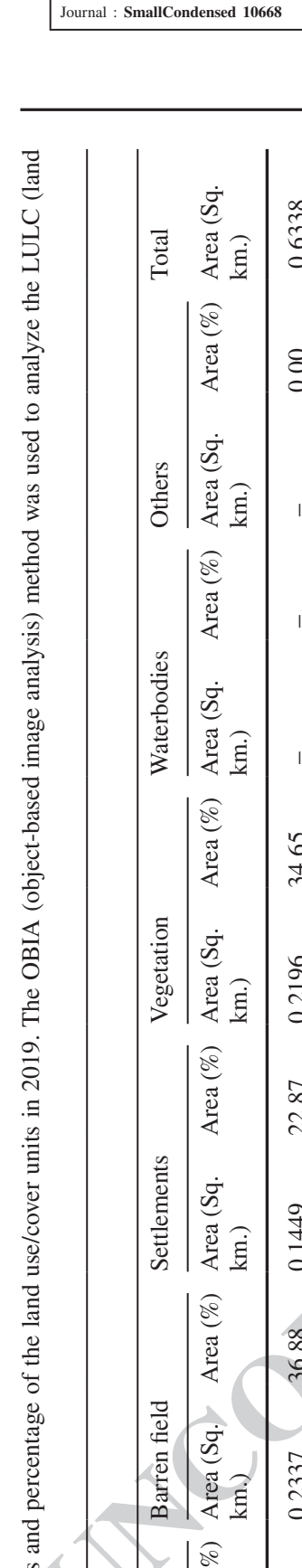

.

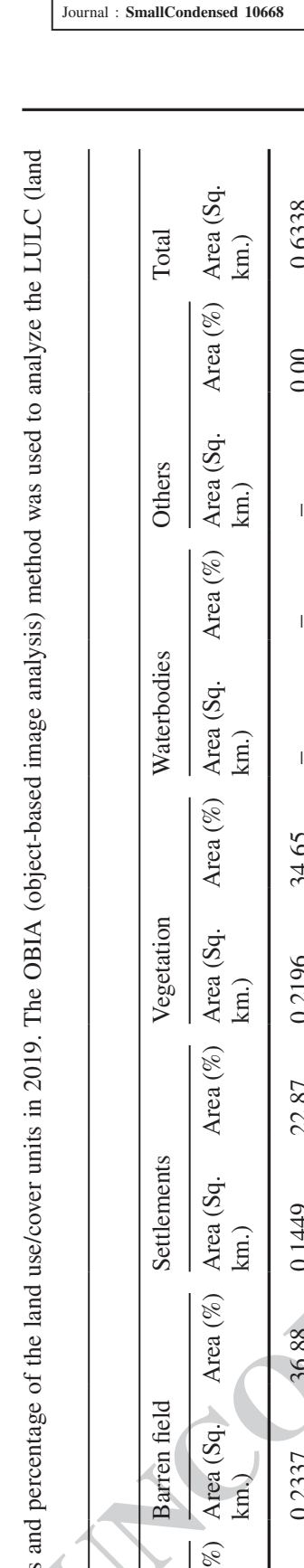

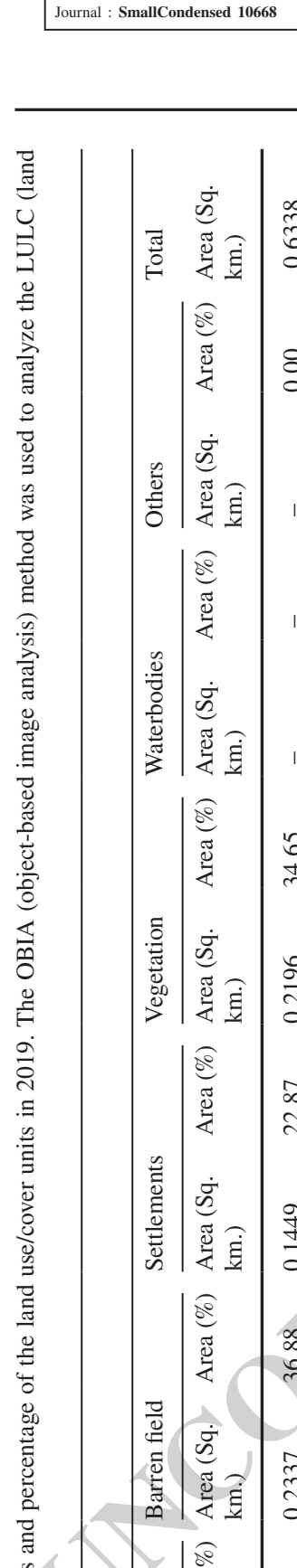

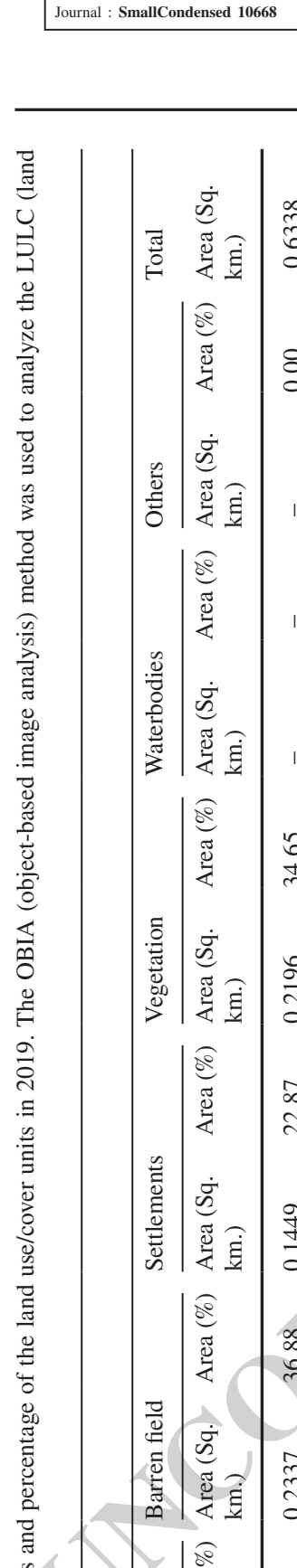

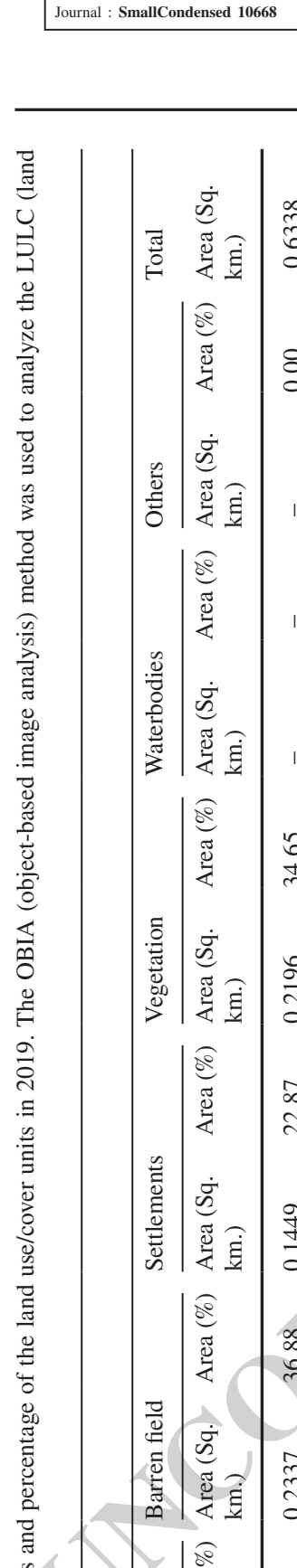

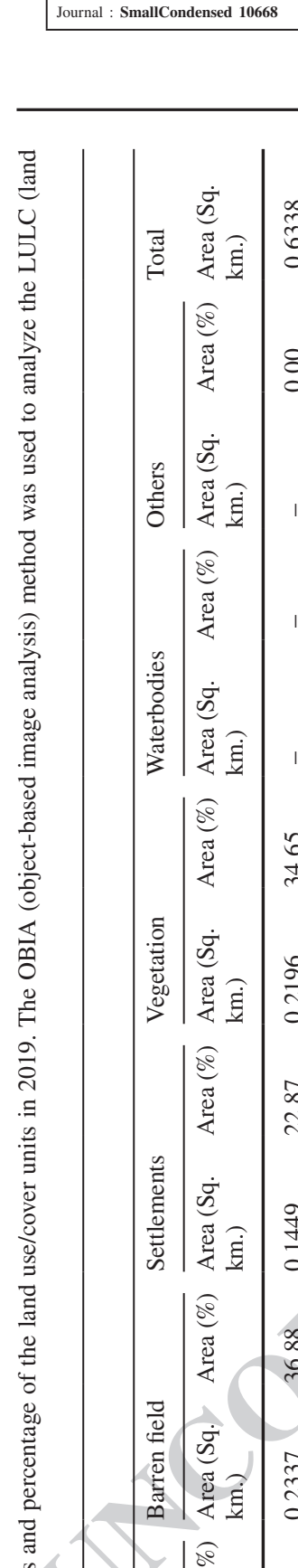

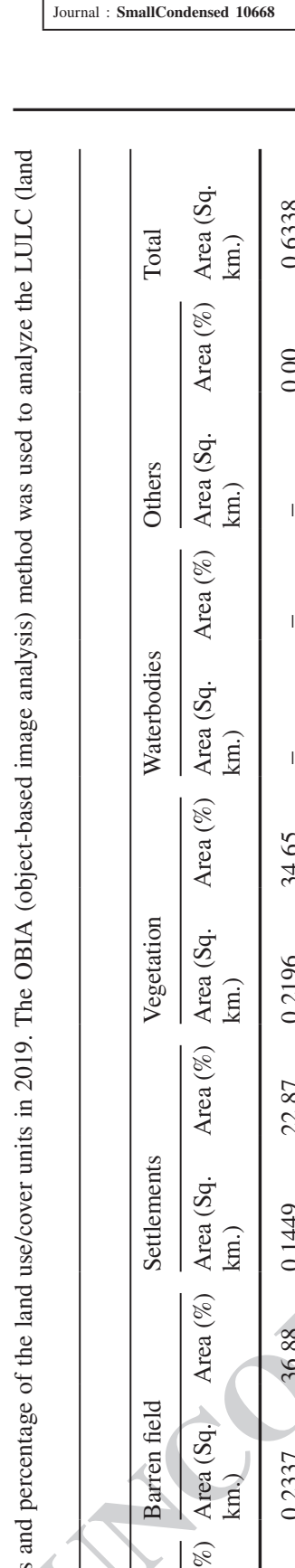

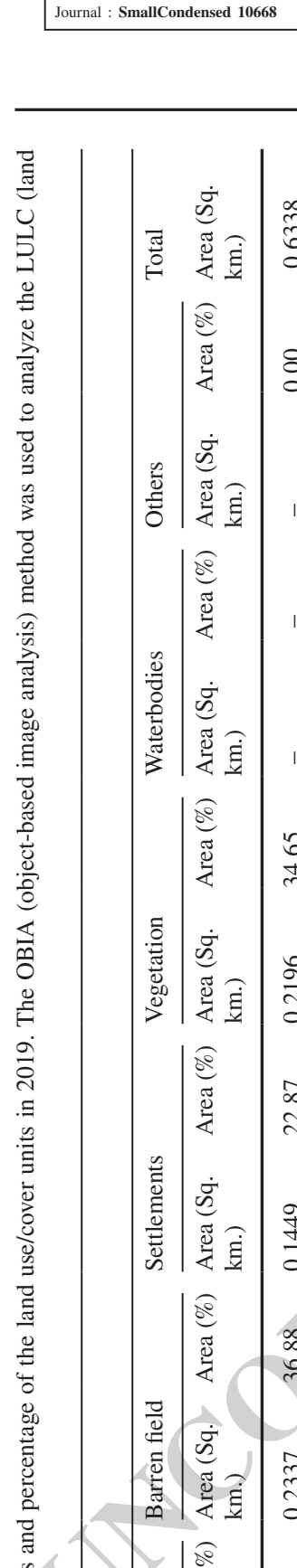

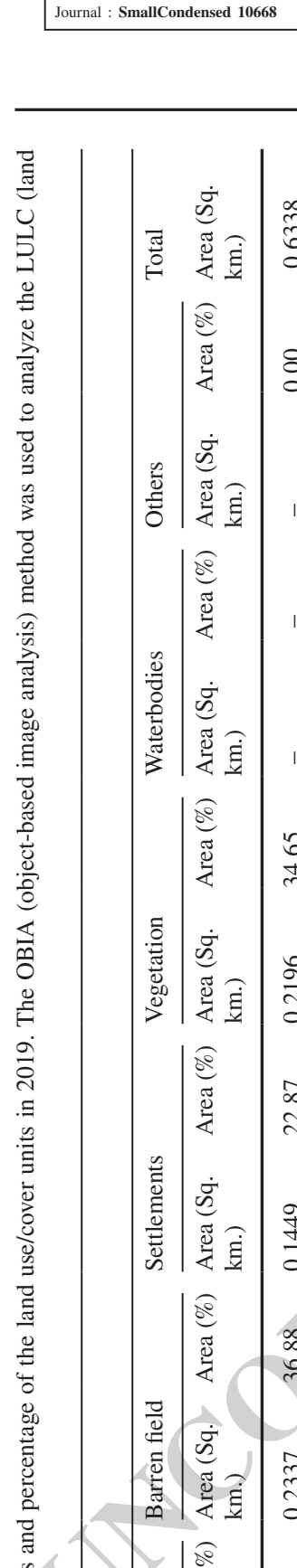

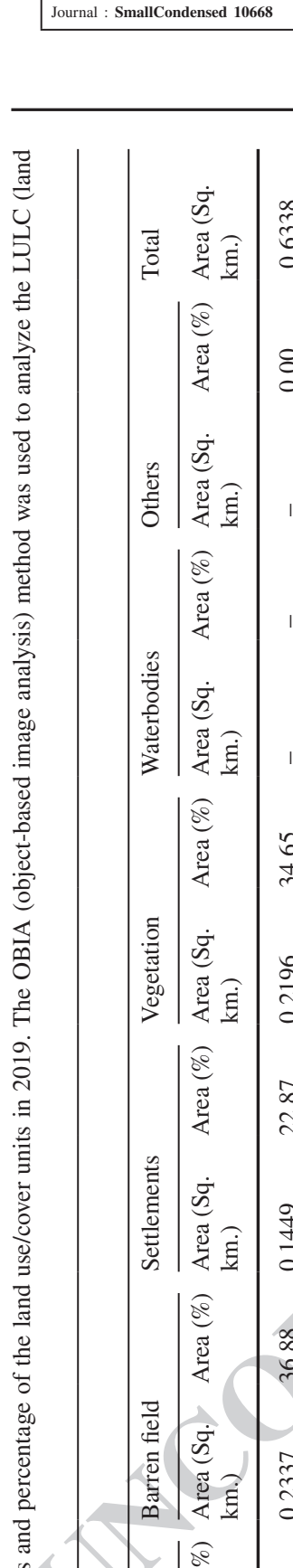

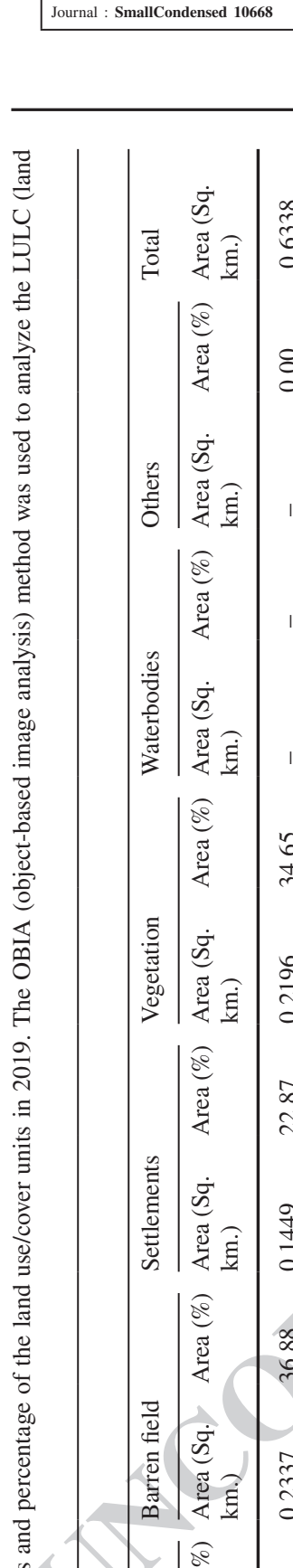

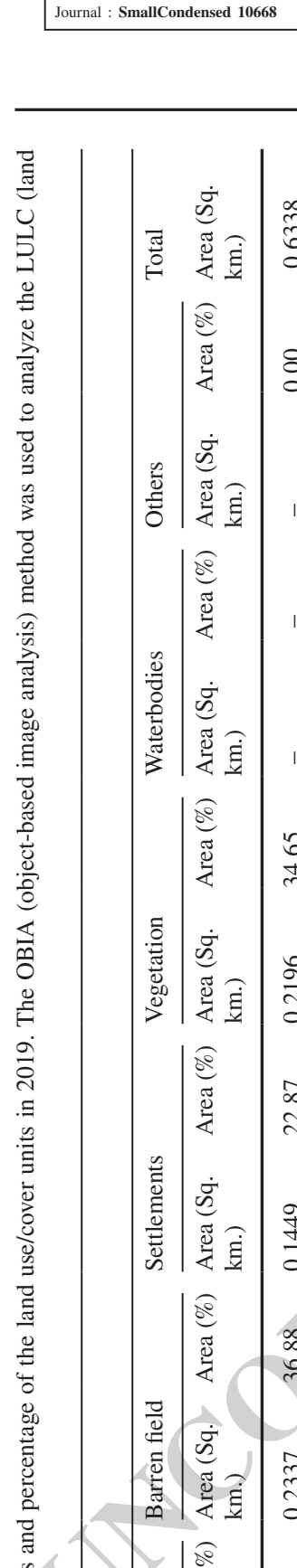

两

.

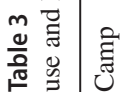

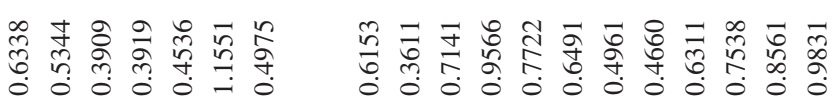

인

$1, \frac{n}{8}$

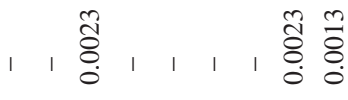

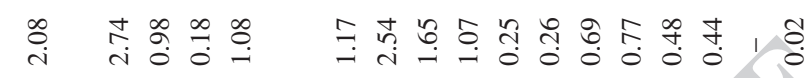

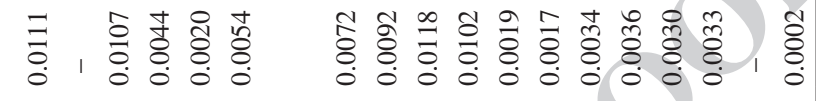

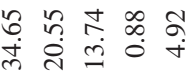

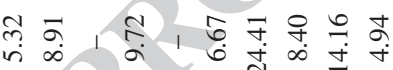

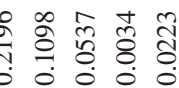

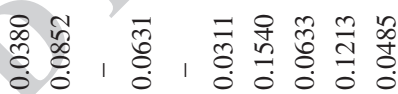

क음

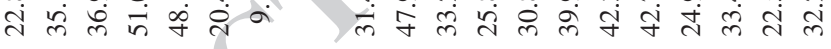

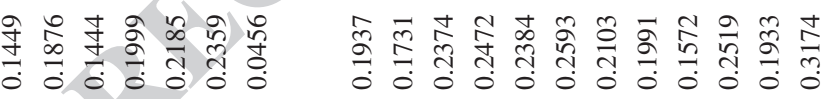

$\infty$ \& तो

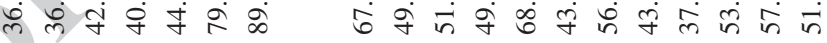

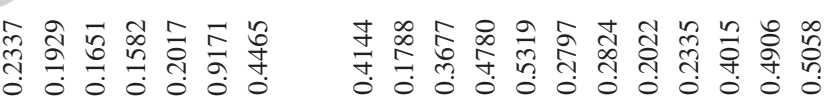

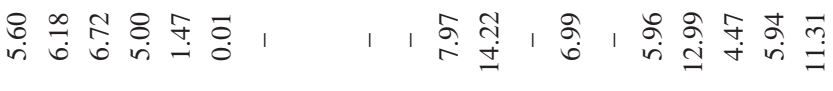

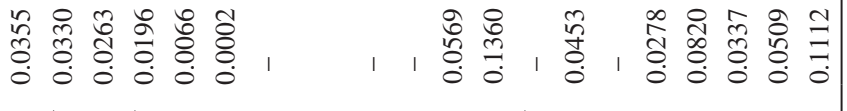

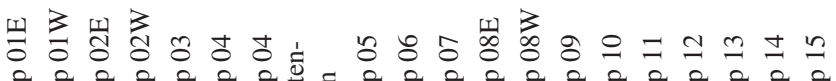

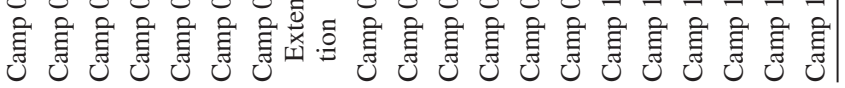




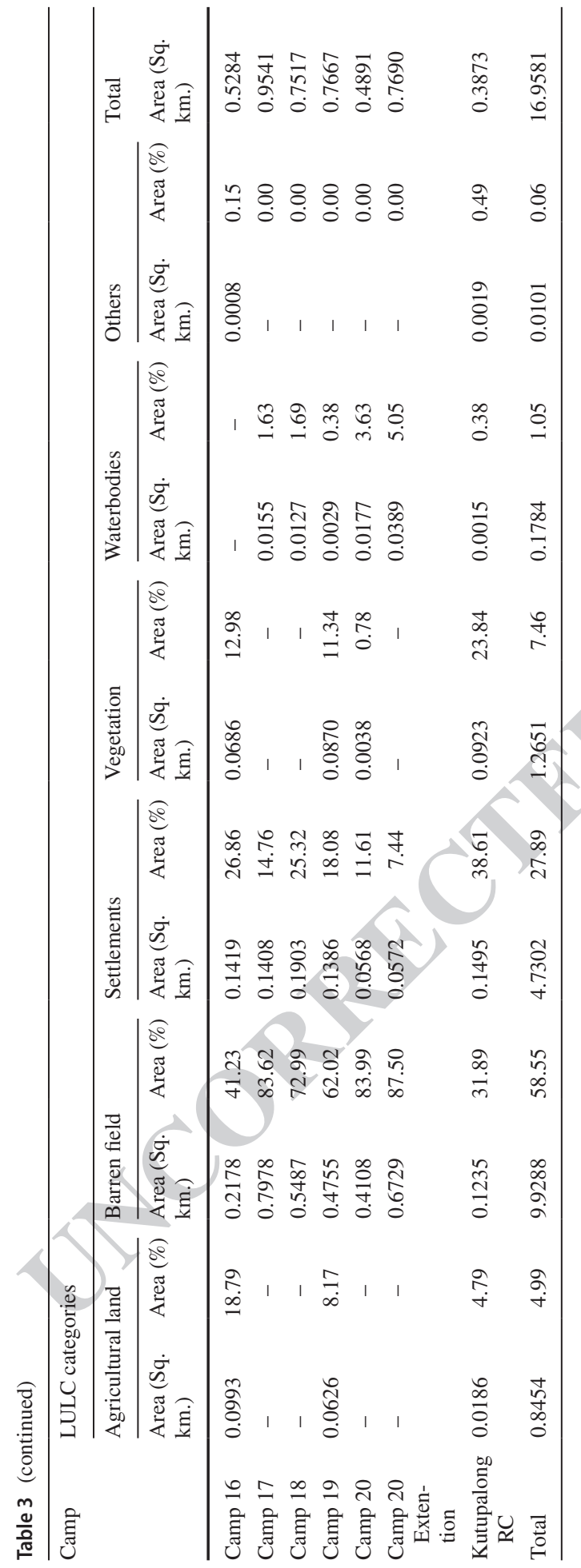




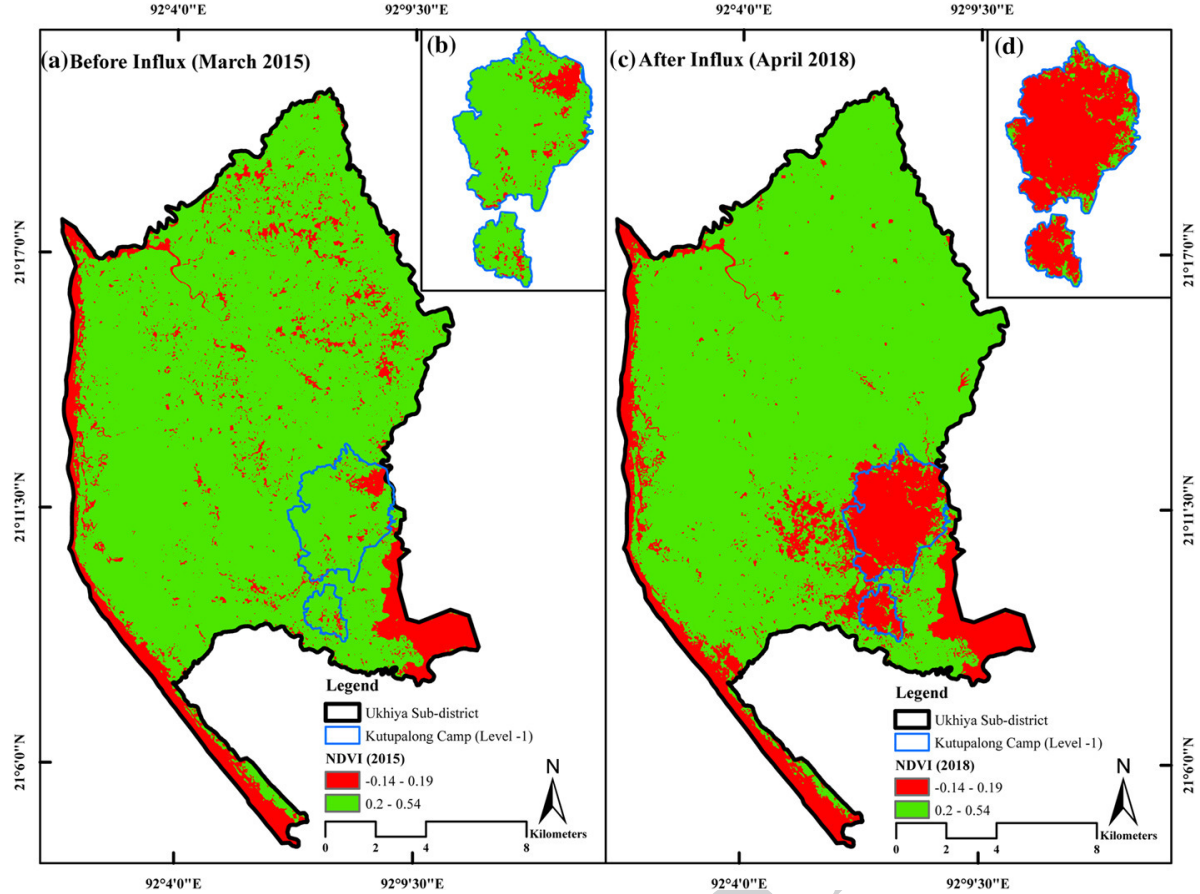

Fig. 5 NDVI analysis of the study area between March 2015 and April 2018. Green tones indicate vegetated areas while the red tones indicate loss of vegetation. a NDVI raster map of the Ukhiya sub-district before Rohingya influx; b NDVI raster map of the Kutupalong campsite before Rohingya influx; c NDVI raster map of the Ukhiya sub-district after Rohingya influx; d NDVI raster map of the Kutupalong campsite after Rohingya influx

Table 4 Area (in sq.km) changes in NDVI analysis between 2015 and 2018 in the Ukiya Upazila and Kutupalong camp area

\begin{tabular}{|c|c|c|c|c|c|c|}
\hline \multirow{3}{*}{$\begin{array}{l}\text { Year } \\
\text { NDVI class }\end{array}$} & \multirow{2}{*}{\multicolumn{2}{|c|}{$\frac{2015}{\text { Vegetation Non-vegetation }}$}} & \multicolumn{2}{|l|}{2018} & \multirow{2}{*}{\multicolumn{2}{|c|}{$\begin{array}{l}\text { Decline Rates of vegeta- } \\
\text { tion area between } 2015 \\
\text { and } 2018\end{array}$}} \\
\hline & & & \multirow{2}{*}{$\begin{array}{l}\text { Vegetation } \\
\text { Area (sq.kn }\end{array}$} & \multirow[t]{2}{*}{ Non-vegetation } & & \\
\hline & \multicolumn{2}{|c|}{ Area (sq.km.) } & & & Area (sq.km.) & Percent (\%) \\
\hline Ukhiya Upazila & 164.47 & 94.77 & 125.08 & 134.16 & 39.39 & 15.20 \\
\hline Kutupalong Camp & 11.69 & 5.26 & 0.46 & 16.49 & 11.23 & 66.25 \\
\hline
\end{tabular}

From the geospatial analysis, it is found that because of the expansion of Rohingya resettlement in the Ukhiya sub-district, significant changes of vegetation cover occurred. The NDVI assessment covers both Ukhiya Upazila and Kutupalong camp. The result indicates that the NDVI values for the study area varied mostly from -0.1 to 0.54 . Figure 5 shows the NDVI maps for the years 2015 and 2018. NDVI values of the vegetation area ranges from 0.2 to 0.54 and the non-vegetated area ranges from -0.14 to 0.19 . The 2015 NDVI map (Fig. 5a) indicates that there was a total of 164.47 sq.km vegetation 
area which covers $63.44 \%$ land of the total area in Ukhiya Upazila before Rohingya exodus and it was reduced to $48.24 \%$ of the total land area in 2018 (Fig. 5b).

Again, NDVI analysis revealed that in April 2015, preceding the major Rohingya influx, the camp area covers 11.69 sq.km green area (Table 4). These areas have declined to 0.46 sq.km (Fig. 6) because of anthropogenic activities of Rohingya people who have been settled in the area.

\subsection{Rohingya refugee and forest resource depletion}

The results from the responses of the questionnaire participants also support the findings from the geospatial analysis. The forest resources of Kutupalong camp and it's surrounding area significantly reduced due to the refugee settlement and their dependency on forest resources in various direct and indirect means.

The dataset provided in Table 5 reveals that about $96 \%$ of participants recounted that the hills were covered with forest when they migrated there in 2017. In contrast, now, an aerial view of this area looks like a labyrinth built on a hillside, full of asylum-seeker's shelters constructed of polythene, tarpaulins, and associated debris. A verdant green forest was altered into the garbage, a wasteland denuded of vegetation and occupied by temporary shelters within a couple of years due to anthropogenic activities. Most of the material for the shelters come from NGOs. About $47 \%$ of respondents said that NGOs assisted them to build their temporary shelters, while $33 \%$ responded that the construction materials were collected by their own effort. And, the study found that there is a linkage between forest resource depletion and the construction material of Rohingya resettlement.

Similarly, the result shows Rohingya people are responsible for the depletion of forest resources in terms of fuel collecting. From Table 5 we found that the majority $(61 \%)$ responded used wood for fuel, while the Government of Bangladesh (in a bid to reduce forest destruction) offered to supply LPG (Liquefied Petroleum Gas), an option is taken by $35 \%$ of respondents; others used kerosene or an electric coil (2\%) which they bought from a local market. And, most of the fuelwood comes directly or indirectly from the forest area. The survey result shows $18 \%$ of participants reported their fuelwood comes directly from nearby forests by cutting the tree. Besides that, $43 \%$ of respondents reported sourcing wood
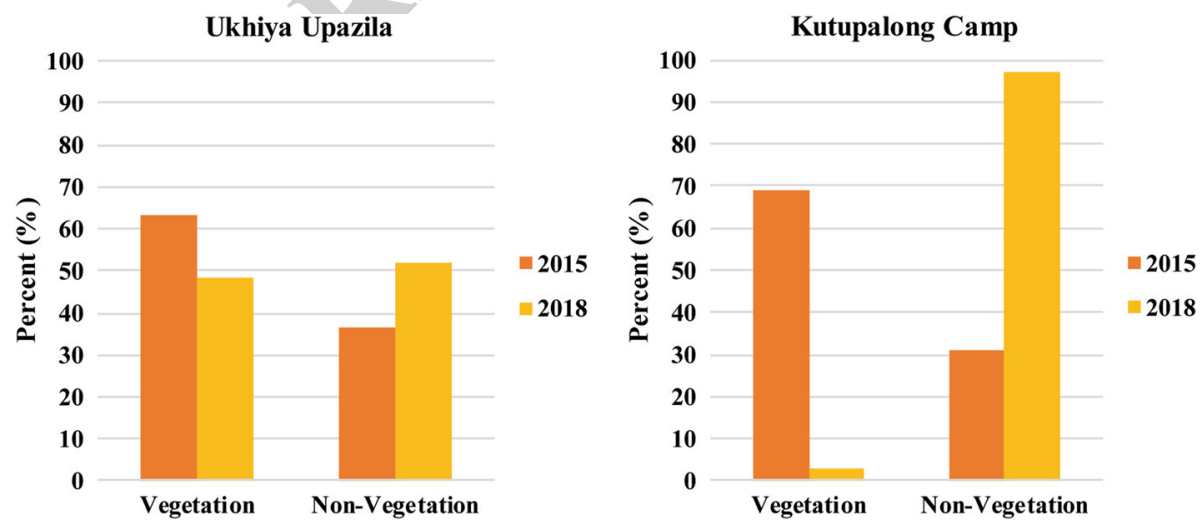

Fig. 6 Bar chart displays the comparison of the amount of vegetation and non-vegetation in the Ukhiya subdistrict and Kutupalong campsite in percentage for the years 2015 and 2018. The orange and gold colour represent vegetation and non-vegetation area for the year 2015 and 2018, respectively 

ticipants of the questionnaire survey

\begin{tabular}{llll}
\hline Characteristics & Percentage (\%) & Characteristics & Percentage (\%) \\
\hline Previous pattern of terrain & & Sources of fuelwood & \\
Forest cover & 96.3 & Directly cut from nearest forest & 18 \\
Plain Land & 0.5 & Local market & 43 \\
Grass Land & 0.8 & NGO & 33 \\
Agricultural Land & 1.7 & Others & 6 \\
Source for shelter building materials & & Sources of LPG & \\
Self-collected & 33 & Local market & 14 \\
NGO & 47 & NGO & 31 \\
Bangladesh government & 20 & Bangladesh government & 55 \\
Types of fuel used by refugee & & Other & 0 \\
LPG & 35 & Drivers of forest cover change & \\
Wood & 61 & Fuel collection & 51 \\
Kerosene & 2 & Building shelter & 24 \\
Electric Coil & 2 & Woodcutting for selling & 14 \\
& & Other & 11 \\
\hline
\end{tabular}

for fuel comes via the local market and that has also the connection with the nearby forest. Therefore, this ongoing use of wood for fuel is the main reason for forestry depletion in Ukhiya sub-district. Some $33 \%$ of refugees/asylum seekers reported obtaining their wood for fuel from NGOs. The main LPG provider is the Government of Bangladesh which, together with NGOs, is also providing LPG in some blocks of the Kutupalong camps.

The study thus reveals that the majority of Rohingya access forest timber directly or indirectly to meet their fuel needs and to construct their shelters. About $51 \%$ of respondent told that they use forestry resources for their fuel and $24 \%$ told that they did so to build their shelters/houses. About $14 \%$ of respondents felled trees to sell in the market. Some respondents observed that as they are collecting fuelwood from the market or NGOs, they don't need to cut trees from the forest.

\subsection{Rohingya people, ecosystem services and environmental changes}

The rapid and overwhelming influx of Rohingya evacuees into the hilly territory of the Ukhiya sub-district has disturbed the entire environmental cycle of the forested zone. The forest ecosystem falls into confusion due to sudden anthropogenic activities associated with the settlement, for example often ill-advised slope cutting, as well as road and stair building, etc.

The entire forest ecosystem is disrupted due to the Rohingya influx. Verdant land, including wildlife sanctuaries and reserves, are affected. Survey results demonstrate that about $96.3 \%$ of participants acknowledged that the camp area was once verdant land. However, countless trees were chopped down for their everyday needs and building houses which had an incredible effect on forestry ecological services. Nearby local Bangladeshi inhabitants of Ukhiya sub-district are currently denied access to forestry assets in the camp support zone. At whatever point a camp ascends over the sloping territory, local people 
lose their rights and traditional access to forestry. Because of deforestation, these previously wooded areas are also losing their aesthetic value.

The aquatic ecosystem is also devalued by the influx of some local streams diverted or local watercourses filled in during the construction of streets and stairs. Moreover, some of the watercourses that are not filled in during the construction of their temporary shelters are contaminated by discarded rubbish, human waste, and polythene dumped by the asylum seekers. In addition, tube wells dug for access to drinking water may be polluted due to lack of adequate sanitation (threatening human health) and further contaminate the aquifer; they also struggle to meet the need for water and many required rehabilitation or replacement (GFDRR 2018). Illegal slope cutting, with flow disruption, increased landslide risk, increased silting and concomitant flood risk, combined with pollution is harming the entire water basin in the forestry area. Accordingly, the forest areas' aquatic ecosystem faces many and great dangers to any continuing healthy existence. As a result, other people nearby will lose their freshwater-bodies and water resources that they were able to access before the Rohingya influx. Without amelioration or rectification, such losses can also lead to longer-term inter-community resentment and strife.

In the same vain, Jhum (slash and burn) cultivation was also influenced by the influx. Approximately $2 \%$ of respondents reported that there was little horticultural land where local people could cultivate crops. What little had existed, however, has been destroyed by Rohingya people for their refugee camps which are having an extraordinary effect on natural and agricultural environments. Native (Bangladeshi) individuals are presently denied access to jhum cultivation because of the extent of forestry destruction and slope cutting. Trash dumped by refugees/asylum seekers also reduces soil quality and makes the land less prolific if agriculture is attempted.

\subsection{Refugee settlement, hill cutting activities, and increases of risk to natural hazards}

The study observed that significant hill cutting activities occurred in the Rohingya camps and their surrounding area that increased the risk of natural hazards such as flooding and landslide. Generally, hill degradation occurs due to some major causes like hill or slope cutting, removal of forest cover, construction of roads in a hilly area, jhum cultivation, etc.

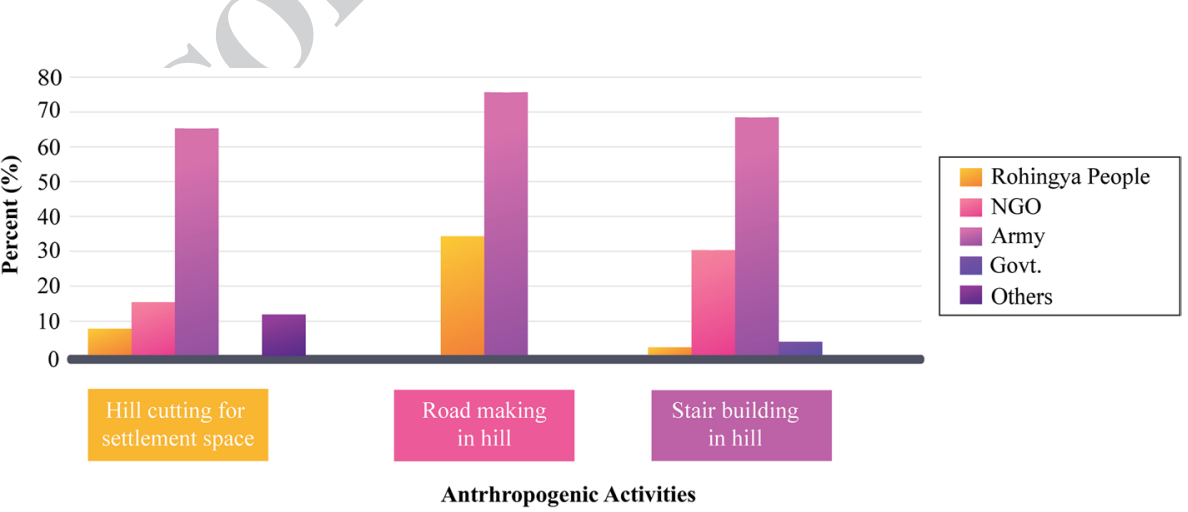

Fig. 7 Graphical distribution of hill cutting activities by anthropogenic activities, showing the type of activity and actor, as a percentage (\%) 
Nowadays Ukhiya sub-district is facing hill degradation due to all of the above anthropogenic activities that are associated with the Rohingya influx in forest areas. Figure 7 demonstrates that most hills are cut by Rohingya people themselves, NGO's and the government agency for constructing houses in the camps. The streets are made by the Bangladesh government for the more effective and comfortable transportation of displaced people.

Two broad settlement risk classes, namely-settlement at risk and settlement at no risk indicated the risky settlement area due to flood and landslide in kutupalong camp (Fig. 8). The output of the risk assessment presents that out of total settlement $0.35 \%$ and $9.61 \%$ settlements are at risk of landslide and flood, respectively.

The landslide risk map (Fig. 8a) represent that the camp number 04 extension has the highest percentage of settlements $(21 \%)$ are at risk (Table 6). Ten other camps (number $01 \mathrm{~W}, 02 \mathrm{~W}, 03,05,06,08 \mathrm{E}, 08 \mathrm{~W}, 10,11$ and 14) have the more than $10 \%$ settlements that are exposed to landslide. Field observation reveals that many of the Kutupalong camps already lie in a zone highly vulnerable to landslide and inland flood. Also, excessive hill cutting and deforestation increased risks of landslide and inland flooding in camp areas. Deforestation and hill cutting enervated the strength of soils that had previously been held together by vegetation, making them fragile and increasingly susceptible to the landslide. In the monsoon season, excessive rainfall will further complicate the access to and within the camps, further increasing landslide risk and the potential for fatalities.

On the other hand, flood risk map (Fig. 8b) indicates that the camp number 09 and 10 has the highest percentage ( $14.87 \%$ and $14.78 \%$, respectively) of settlements that are at risk to flooding (Table 6). The camp number 01E, 02E, 02W, 11, 12, 13 and 19 have more than
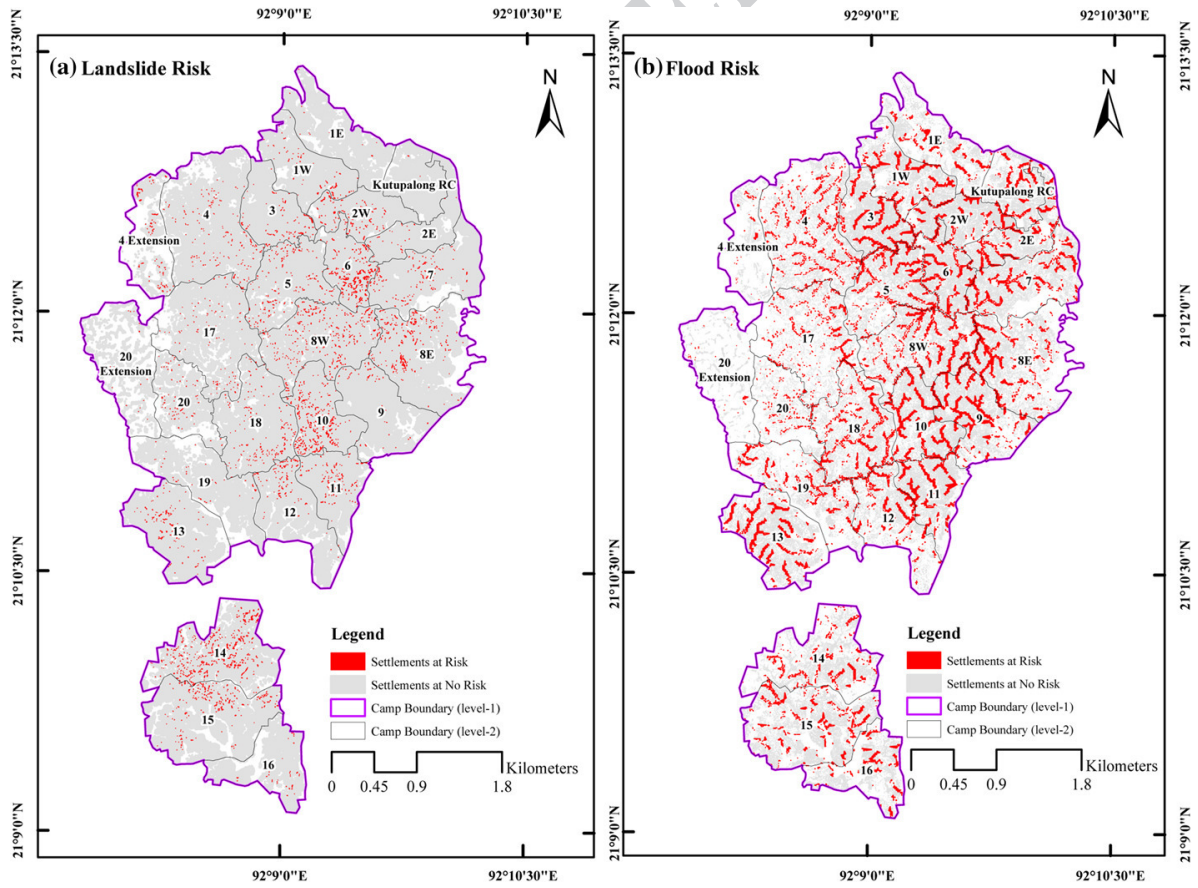

Fig. 8 Settlements at risk due to landslide and flood hazards. Grey tone indicates settlement at no risk and red tone indicates the settlement at risk. a Landslide risk map; b flood risk map 
Rohingya refugee flooding and changes of physical and social...

Table 6 Camp wise settlement area at risk to landslide and flood. The output is based on mixed-method which is developed by IOM, UNCHR, and ADPC

\begin{tabular}{|c|c|c|c|c|}
\hline \multirow[t]{3}{*}{ Camp } & \multicolumn{4}{|l|}{ Hazard } \\
\hline & \multicolumn{2}{|l|}{ Landslide } & \multicolumn{2}{|l|}{ Flood } \\
\hline & Area (Sq.km.) & Area (\%) & Area (Sq.km.) & Area (\%) \\
\hline Camp 01E & 0.00006 & 0.04 & 0.01530 & 10.56 \\
\hline Camp 01W & 0.00046 & 0.25 & 0.01673 & 8.92 \\
\hline Camp 02E & 0.00013 & 0.09 & 0.01706 & 11.82 \\
\hline Camp 02W & 0.00089 & 0.45 & 0.02085 & 10.43 \\
\hline Camp 03 & 0.00049 & 0.22 & 0.02093 & 9.58 \\
\hline Camp 04 & 0.00041 & 0.18 & 0.01481 & 6.28 \\
\hline Camp 04 Extention & 0.00069 & 1.52 & 0.00134 & 2.95 \\
\hline Camp 05 & 0.00058 & 0.30 & 0.01751 & 9.04 \\
\hline Camp 06 & 0.00152 & 0.88 & 0.01664 & 9.61 \\
\hline Camp 07 & 0.00055 & 0.23 & 0.02141 & 9.02 \\
\hline Camp 08E & 0.00144 & 0.58 & 0.02419 & 9.79 \\
\hline Camp 08W & 0.00121 & 0.51 & 0.02370 & 9.94 \\
\hline Camp 09 & 0.00027 & 0.10 & 0.03839 & 14.81 \\
\hline Camp 10 & 0.00154 & 0.73 & 0.03109 & 14.78 \\
\hline Camp 11 & 0.00068 & 0.34 & 0.02674 & 13.43 \\
\hline Camp 12 & 0.00043 & 0.28 & 0.01874 & 11.92 \\
\hline Camp 13 & 0.00052 & 0.21 & 0.02776 & 11.02 \\
\hline Camp 14 & 0.00265 & 1.37 & 0.01098 & 5.68 \\
\hline Camp 15 & 0.00100 & 0.31 & 0.01864 & 5.87 \\
\hline Camp 16 & 0.00021 & 0.14 & 0.01182 & 8.33 \\
\hline Camp 17 & 0.00020 & 0.14 & 0.01157 & 8.22 \\
\hline Camp 18 & 0.00039 & 0.20 & 0.01820 & 9.56 \\
\hline Camp 19 & 0.00014 & 0.10 & 0.01429 & 10.31 \\
\hline Camp 20 & 0.00024 & 0.42 & 0.00268 & 4.72 \\
\hline Camp 20 Extention & 0.00005 & 0.08 & 0.00061 & 1.07 \\
\hline Kutupalong RC & 0.00002 & 0.01 & 0.01263 & 8.45 \\
\hline Total & 0.01674 & 0.35 & 0.45461 & 9.61 \\
\hline
\end{tabular}

$10 \%$ settlements and rest have less than $10 \%$ settlements that are at risk to flood. Different kinds of shelters and road networks were constructed for refugees by filling the natural waterways of the area and runoff channels from the forest area which are the main reason for inland flooding. Additionally, water basins of the forest area have been damaged by the distinct anthropogenic activities by Rohingya peoples, raising the risk for inland flood.

Similarly, in Fig. 9, image 01 shows that some of the shelters lie in a precarious position in terms of extreme risk of landslide due to hill degradation; these areas are also vulnerable to inland flooding due to filling in the channel and so impeding the surface water runoff to the water basin. Image 02 shows how refugees, by constructing an embankment, are seek-

48 ing to protect their agricultural land from rainwater flows and flooding. Image 03 of a mar9 ket place within the camps shows the use of fill (cut from hillsides) as a foundation for the market place and housing (clearly visible in the background as is the denuded hillside). It 


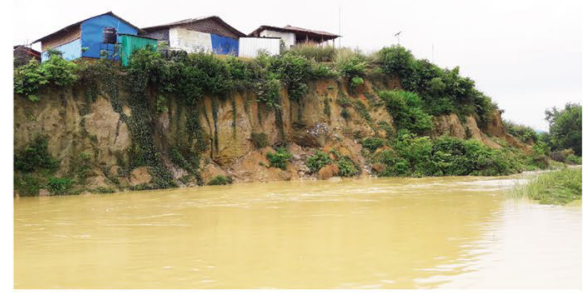

\section{Image-01}

Acquisition date: $28-08-2018$

Location: Camp No-09

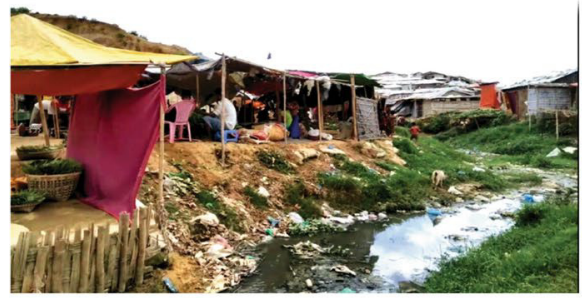

\section{Image-03}

Acquisition date: $29-08-2018$

Location: Camp No-8W, Block-5D

M. A. Quader et al.

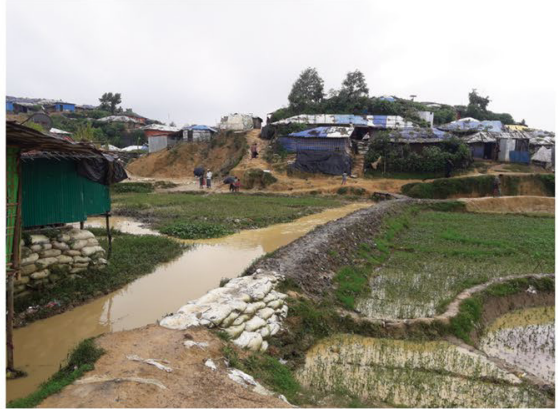

\section{Image-02}

Acquisition date: 28-08-2018

Location: Camp No-05, Block-1B

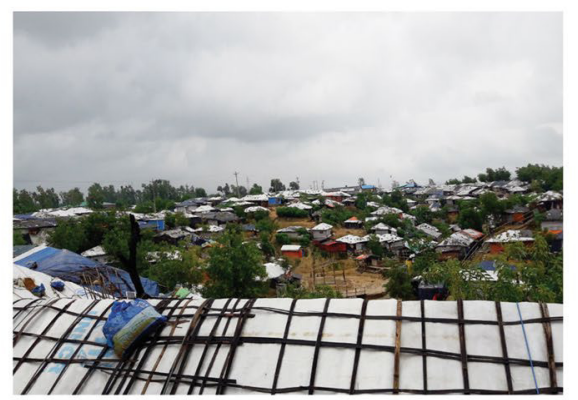

Image-04

Acquisition date: $29-08-2018$

Location: Camp No-06, Block-0A

Source: Field Survey, 2018

Fig. 9 Examples of the refugee impacts in the Ukiya sub-district. The pictures are showing the impact of refugee camps on the topography, environment, and public health

also shows pollution of the diverted waterway beside it and the presence of animals whose waste would contribute to water pollution in the area, together with plastic and other rubbish discarded by refugees that are visible in and beside the waterway. Image 04 shows that a verdant forest has been altered to a slum-like area within a year. There is little appearance of green vegetation when one looks all around the tarpaulin and polythene sheet dwellings made by asylum seekers. These photographs all demonstrate the present physiographical conditions of the Rohingya camps due to anthropogenic activities.

\section{Discussion}

This article provides an in-depth understanding about the consequence of the Rohingya influx on forest resources and the physical landscape of Ukhiya sub-district of Bangladesh and the associated socio-economic impact on the local community. To identify the consequence of vegetation cover changes, data were extracted from the satellite images in two different times of before and after the flooding of Rohingya people. 
Moreover, face to face survey interview was conducted to illustrate the context-specific impact of Rohingya intrusion on ecosystem services and socio-economic structures.

The study found that forest cover is reducing significantly because of the increasing demand of house building materials, forest wood to use as fuel, and so forth. Although Hassan et al. (2018) found that Bangladesh lost 5641.41 acres (from 2015 to 2017) of forest land because of Rohingya influx in the surrounding of Kutupalong-Balukhali, Unchiprang, and Nayapara-Leda campsites while our study shows that the vegetation cover reduced around 2775 acres between 2015 and 2018 in Kutupalong camp area Therefore, the land surface temperature (LST) of Kutupalong-Balukhali and surrounding region has increase $1.3{ }^{\circ} \mathrm{C}$ between 2017 and 2019 (Rashid et al. 2020). There are two major reasons for this forest degradation. First, to provide space and materials for building a shelter camp for Rohingya people. Second, forest resources used as fuel for regular cooking. Therefore, it appears that the depletion of forest resources is ongoing. Based on the evidence of the reduction of forest cover in this area, we predict, the remaining forest resources also would soon be converted into open land because of the ongoing use of forest resources for different purposes (The Daily Sun 2017; Hassan et al. 2018).

This research provides first-hand information regarding the forest cover degradation for this particular area. The study shows that to accommodate the large group of Rohingya people, 9.96 sq. km area of forest cover has been cleaned in the study area that affecting the local community as well as the global environment. The study shows, Rohingya people directly collect wood from the nearby forest for cooking. Even, they reported that NGOs provided fuelwood and the fuelwood bought from the local market are also indirectly comes from the nearby forest. Therefore, the high demand for wood for cooking and building materials causes the destruction of ecosystem services. Many flora and fauna are reported as at danger and some of them have already been at extinct (The Dhaka Tribune 2017; BD News24 2017; Hassan et al. 2018). Nevertheless, excessive slash and burn agriculture would itself pose a problem to the ecosystem, and where it is practiced with more frequent rotations, soil quality is again rapidly depleted (Islam 2014).

The increasing dependency of Rohingya people on forest cover also creates conflict with native people. It is found that native people have deprived of the access to the local forest because of Rohingya refugee. A couple of fighting has occurred between Rohingya and native Bangladeshi and few of them ended up with human loss (Reliefweb 2019; The New Age 2019). Although the native Bangladeshi people have sympathy to Rohingya refugee, however, drug peddling, drug transport and other various crimes continuously undertaken by Rohingya people has fuelled local people to fear about them (Kader and Choudhury 2019; Hassan et al. 2018; The Daily Star 2019). Moreover, native people lost their job because of cheaper labour offered by Rohingya people.

A combined study released by IOM-UNHCR-ADPC in January 2018 estimated that almost 150,000 Rohingya people are in the vulnerable zone to floods and landslides in their current locations. Our result shows that the hill cutting activities to build shelter, road, and embankment decreases the average elevation from the sea level that increases the flood risk of many Rohingya settlers (See Fig. 8b). Moreover, it also increases the landslide possibility during the rainy season which may cost human deaths (see Fig. 8a). From the questionnaire survey, it is found that hill cutting for various purposes produce vulnerability to landslides and floods for both Rohingya people and local settlers. 


\section{Conclusion}

Numerous investigations conclude that the Rohingya influx of 2017 has had a drastic effect on the condition of the Teknaf Peninsula and Ukhiya sub-district (Imtiaz 2018; Labib et al. 2018; GFDRR 2018; Hassan et al. 2018). Overall, the current study objectively identified that forestry cover decreased by about $66.25 \%$ because of the convergence of evacuees in Ukhiya sub-district through the use of geographical data collection and comparison while the survey identified the sources of such deforestation and it impacts on ecosystem services and socio-cultural landscape.

Similarly, this investigation reveals that approximately 66 trees are removed from every 100 trees of the forest in association with the resettlement of Rohingya into this forested zone. To meet their need for materials for dwelling construction and for their daily fuel needs, timber and other materials (kindling, twigs, small branches) are collected from virgin forests in and adjacent to the camp. This poses a tremendous danger to the forestry assets of Ukhiya. The natural incline of the area is also being affected because of slope cutting for constructing streets, making space for safe houses and stairs. NGOs and the Bangladesh government agencies are helping evacuees in their efforts to create a refugee camp for them in a new land after fleeing Myanmar. In spite of the fact that these exercises are benevolent for Rohingya refugees/asylum seekers and unfavourably harming generally the forestry ecological system and their continued existence. Also affected areas of slash and burn agricultural practices (jhum) in the area by the host population, are adversely affecting their livelihoods. However, the primary impact is on virgin and replanted forests, which is depriving the area of the part of its 'lungs', natural carbon sinks, and sources of oxygen.

Should this development continue apace, harsh outcomes can be forecasted. The results will not just affect the external appearance of nature, it will influence the environment more deeply. In the future, the terms 'degradation', 'desertification', 'mass extinction', 'ecological crises', 'ecological collapse', and 'climate change' will be ever more frequently used as impacts are measured not just here but around the globe. To reduce the dire environmental impacts of evacuee resettlement in Bangladesh, the above discussion suggests that the footprint of anthropogenic activities must be kept away from virgin forestry as, without protection, it will be not decimated but destroyed over time and its benefits lost to future generations and the environment generally.

Finally, this study adds empirical evidence in literature by exploring how the Rohingya influx contributes to changes in the physical and social environment. We argue, integrating survey data with geo-spatial data bring more accurate result. The aim of integration of both geo-spatial analysis and survey data analysis is not only to incorporate field data directly but also to validate and increase the reliability of geo-spatial data while other studies only rely on either survey data or geo-spatial data. We believe this study enables a better understanding of how the Rohingya influx influence on forest cover, physical, and social landscape that increase the risk and vulnerability of natural hazards. Therefore, this research will help to policy making for these forced migrated Rohingya people at the local, national, and global levels.

Acknowledgements All the participants of questionnaire survey during field campaign are acknowledged. We are grateful to the interpreters who helped us to understand the local language of Rohingya people in the field. We want to extend our thanks to Elaine Newby for proof reading. Eight students of 8th batch and 9th batch of the department of Geography and Environment, Jagannath University helped during the field work. We are grateful to all of them. Finally, we acknowledge greatly the anonymous reviewers who gave considerable effort to improve the manuscript. 


\section{Compliance with ethical standards}

Conflict of interest No potential conflict of interest was reported by the authors.

\section{References}

Ahmed, B., Rahman, M. S., Sammonds, P., Islam, R., \& Uddin, K. (2020). Application of geospatial technologies in developing a dynamic landslide early warning system in a humanitarian context: The Rohingya refugee crisis in Cox's Bazar, Bangladesh. Geomatics, Natural Hazards and Risk, 11(1), 446-468.

Alex, E. C., Ramesh, K. V., \& Sridevi, H. (2017). Quantification and understanding the observed changes in land cover patterns in Bangalore. International Journal of Civil Engineering and Technology, 8(4), 597-603.

Amnesty International (2016). Amnesty International Report 2015/16: The state of the world's human rights. Amnesty International. Retrieved 29 October, 2018, from https://www.amnesty.org/en/docum ents/pol10/2552/2016/en/.

BBS (Bangladesh Bureau of Statistics). (2013). District Statistics 2011 Cox's Bazar. Statistics and Information Division (SID), Ministry of Planning, Government of Bangladesh (GoB). Retrieved 23 March, 2019, fromhttp://203.112.218.65:8008/WebTestApplication/userfiles/Image/District\%20Statistics/ Cox\%60s\%20Bazar.pdf.

Bdnews24.com. (2017). Newly arrived Rohingya refugees Damaged Tk 1.5bn Bangladesh Forest, Govt Says. Retrieved 19 April, 2020, fromhttps://bdnews24.com/environment/2017/10/11/newly-arrivedrohingya-refugees-damaged-tk-1.5bn-bangladesh-forest-govt-says.

Bdnews24.com. (2019). Murder of local Jubo League leader sparks protests, vandalism of Rohingya camp $\mathbf{A Q 4}$ in Teknaf. Retrieved 18 April, 2020, from https://bdnews24.com/bangladesh/2019/08/23/murder-oflocal-jubo-league-leader-sparks-protests-vandalism-of-rohingya-camp-in-teknaf.

Chowdhury, S. Q., \& Hossain, M. S. (2015). Flood. In S. Islam, S. Miah, M. Khanam \& S. Ahmed (Eds.), Banglapedia: The National Encyclopedia of Bangladesh (Online ed.). Dhaka, Bangladesh: Banglapedia Trust, Asiatic Society of Bangladesh. ISBN: 984-32-0576-6. OCLC 52727562. Retrieved 03 May, 2020, from https://en.banglapedia.org/index.php?title=Flood.

Daniel, W. W., \& Cross, C. L. (2018). Biostatistics: A foundation for analysis in the health sciences. New York: Wiley.

Fedele, G., Desrianti, F., Gangga, A., Chazarin, F., Djoudi, H., \& Locatelli, B. (2016). Ecosystem-based strategies for community resilience to climate variability in Indonesia. In F. G. Renaud, K. SudmeierRieux, M. Estrella, \& U. Nehren (Eds.), Ecosystem-based disaster risk reduction and adaptation in practice. Advances in natural and technological hazards research series (Vol. 42, pp. 529-552). Cham: Springer. https://doi.org/10,1007/978-3-319-43633-3_23.

Gandhi, G. M., Parthiban, S., Thummalu, N., \& Christy, A. (2015). NDVI: Vegetation change detection using remote sensing and gis-A case study of Vellore District. Procedia Computer Science, 57, 1199-1210.

GFDRR (Global Facility for Disaster Reduction and Recovery). (2018). Rohingya crisis 2017-2018 draft AQ5 rapid impact, vulnerability and needs assessment: Executive summary. https:/www.gfdrr.org/sites/ default/files/Rohingya\%2520crisis\%2520exec\%2520summary-2.pdf.

Hassan, M. M., Ahmed, S., Patwary, N. H., Yeasmin, L., Shahidullah, S. M., \& Sattar, M. A. (2015). Environmental degradation through hill cutting in Chittagong district of Bangladesh. International Journal of Natural and Social Sciences, 2(3), 41-54.

Hassan, M. M., Smith, A. C., Walker, K., Rahman, M. K., \& Southworth, J. (2018). Rohingya refugee crisis and forest cover change in Teknaf, Bangladesh. Remote Sensing, 10(689), 1-20. https://doi. org/10.3390/rs10050689.

HDX (Humanitarian Data Exchange). (2020a). Contour Lines for Kutupalong Magacamp area and other sites (as of 20 April 2020). https://data.humdata.org/dataset/contour-lines-for-kutupalong-makeshiftsettlement-and-extension-site.

HDX (Humanitarian Data Exchange). (2020b). IOM Bangladesh-needs and population monitoring (NPM) UAV imagery and GIS package by camp (July 2019). https://data.humdata.org/dataset/iom-bangladesh -needs-and-population-monitoring-npm-uav-imagery-and-gis-package-by-camp-july-2019.

Honeth, M., Hixson, A., van Nierop, A., O’Hara, T. E., Vidal, L. C., de Vries, B. S. A., Maddox, W., Cobacho, S. P., Wilson, E. K., O’Rourke, A., Conlon, H. M., Liss, B. M., Cooney, J., Morin, K., \& Guillerme, C. (2017). An investigative environmental impact assessment for Kutupalong refugee 
camp and surroundings, Bangladesh. The Swedish Civil Contingencies Agency. Retrieved 29 January, 2019, from https://www.academia.edu/35916207/An_Investigative_EIA_of_Kutupalong _Refugee_Camp_and_Surroundings_Bangladesh.

Humanitarian Response. (2018). Refugees situation in Cox's Bazar: Risk analysis in Kutupalong-Balukhali expansion area (flood, landslide, services). https://www.humanitarianresponse.info/en/opera tions/bangladesh/infographic/refugees-situation-cox\%E2\%80\%99s-bazar-risk-analysis-kutupalong -balukhali.

Hussain, A. (2018). Rohingya influx, a threat to forest resources. The Dhaka Tribune. Retrieved 11 February, 2019, from https://www.dhakatribune.com/bangladesh/2018/03/20/rohingya-influx-a-threa t-to-forest-resources.

Imtiaz, S. (2018). Ecological impact of Rohingya refugees on forest resources: Remote sensing analysis of vegetation cover change in Teknaf Peninsula in Bangladesh. Ecocycles, 4(1), 16-19. https://doi. org/10.19040/ecocycles.v4i1.89.

Islam, M. S. (2014). Jhum. In S. Islam, S. Miah, M. Khanam, \& S. Ahmed (Eds.), Banglapedia: The National Encyclopedia of Bangladesh (Online ed.). Dhaka, Bangladesh: Banglapedia Trust, Asiatic Society of Bangladesh. ISBN: 984-32-0576-6. OCLC 52727562. Retrieved 03 May, 2020, from https://en.banglapedia.org/index.php?title=Jhum.

Kader, M. F., \& Choudhury, A. H. (2019). Historical background of the Rohingya refugee crisis and the implication of their statelessness. International Journal of Social Sciences and Economic Review, $1(1), 8-15$.

Labib, S. M., Hossain, N., \& Patwary, S. H. (2018). Environmental cost of refugee crisis: Case study of Kutupalong Balukhali Rohingya Camp Site. A remote sensing approach. Poster presented at the 26th GIScience research UK conference (GISRUK 2018), University of Leister. Unpublished. https ://doi.org/10.13140/RG.2.2.14086.22085.

Martin, W. (2017). Strategic recommendations for shelter upgrade in response to the Rohingya humanitarian crisis, findings and results of the emergency market mapping analysis (emma) on bamboo and timber market chains in Cox's Bazar District, Bangladesh. Catholic Relief Services. https:// www.crs.org/sites/default/files/tools-research/bangladesh-shelter-case-study-rohingya-crisis.pdf.

Milton, A. H., Rahman, M., Hussain, S., Jindal, C., Choudhury, S., Akter, S., et al. (2017). Trapped in statelessness: Rohingya refugees in Bangladesh. International Journal of Environmental Research and Public Health, 14(8), 942. https://doi.org/10.3390/ijerph14080942.

Quader, M. A., Agrawal, S., \& Kervyn, M. (2017). Multi-decadal land cover evolution in the Sundarban, the largest mangrove forest in the world. Ocean \& Coastal Management, 139, 113-124.

Rahman, M. H. (2019). Rohingya refugee crisis and human vs elephant (Elephas maximus) conflicts in Cox's Bazar district of Bangladesh. Journal of Wildlife and Biodiversity, 3(3), 10-21. https://doi. org/10.22120/jwb.2019.35217.

Rashid, K. J., Hoque, M. A., Esha, T. A., Rahman, M. A., \& Paul, A. (2020). Spatiotemporal changes of AQ6 vegetation and land surface temperature in the refugee camps and its surrounding areas of Bangladesh after the Rohingya influx from Myanmar. Environment, Development and Sustainability, 79, $1-16$.

Reliefweb. (2019). Bangladesh-Violent incidents in Rohingya refugee settlements (DG ECHO, NGOs) (ECHO Daily Flash of 24 August 2019). Retrieved 20 April, 2020, from https://reliefweb.int/repor t/bangladesh/bangladesh-violent-incidents-rohingya-refugee-settlements-dg-echo-ngos-echo-daily.

Sohel, M. (2017). The Rohingya crisis in Myanmar: Origin and emergence. Saudi Journal of Humanities AQ7 and Social Sciences, 2, 1-12.

The Daily Star. (2018). 4,300 acres of hills, forests razed for Rohingya shelters. Retrieved 01 September, 2019, from https://www.thedailystar.net/rohingya-crisis/rohingya-influx-puts-biodiversity-risk-incoxs-bazar-1635562. (Last modified 26 August 2019).

The Daily Star. (2019). Crimes in the Rohingya camps. Retrieved 21 April, 2020, from https://www. thedailystar.net/editorial/news/crimes-the-rohingya-camps-1722538.

The Daily Sun. (2017). Destruction of forests by Rohingyas. Retrieved 18 April, 2020, from https:// www.daily-sun.com/post/265211/Destruction-of-forests-by-Rohingyas.

The Dhaka Tribune. (2017). Rohingya Influx: 15-year-old forestation project destroyed in 57 days. Retrieved 18 April, 2020, from https://www.dhakatribune.com/bangladesh/2017/10/21/rohingyainflux-15-year-old-forestation-project-destroyed-57-days/.

The Dhaka Tribune. (2018). ICCB: Rohingya related deforestation eats up land worth tk $741.31 \mathrm{cr}$. Retrieved 08 April, 2020, from https://www.dhakatribune.com/bangladesh/2018/08/26/iccb-rohin gya-related-deforestation-eats-up-land-worth-tk741-31cr.

The New Age. (2019). 10 injured in Rohingya camp in Teknaf. Retrieved 20 April, 2020, from https:// www.newagebd.net/article/98573/10-injured-in-rohingya-camp-in-teknaf. 
Rohingya refugee flooding and changes of physical and social...

UNDP Bangladesh and UN WOMEN Bangladesh. (2018). Report on environmental impact of Rohingya Influx. Dhaka, Bangladesh. Retrieved 05 February, 2019, from https://www.undp.org/content/dam/ bangladesh/docs/Publications/Pub-2018/Updated/REIRI.pdf.

UNHCR Population Map. (2019). UNHCR, Bangladesh, Cox's Bazar. UNHCR. https://data2.unhcr.org/en/ documents/details/70839.

Publisher's Note Springer Nature remains neutral with regard to jurisdictional claims in published maps and institutional affiliations.

\section{Affiliations}

\section{Mohammad Abdul Quader ${ }^{1}\left[\right.$ ] $\cdot$ Hemal Dey ${ }^{1} \cdot$ Md. Abdul Malak $^{1,2} \cdot$ Abdul Majed Sajib $^{3}$}

Hemal Dey

hemaldey@gmail.com

Md. Abdul Malak

mam716@uowmail.edu.au

Abdul Majed Sajib

majed.sajib@gmail.com

1 Department of Geography and Environment, Jagannath University, Dhaka 1100, Bangladesh

2 School of Geography and Sustainable Communities, University of Wollongong, Wollongong, NSW, Australia

3 Bangladesh Geographical Information Technology (BGIT), Dhaka 1203, Bangladesh 
Journal: $\quad \mathbf{1 0 6 6 8}$

Article:792

\section{Author Query Form}

\section{Please ensure you fill out your response to the queries raised below and return this form along with your corrections}

\section{Dear Author}

During the process of typesetting your article, the following queries have arisen. Please check your typeset proof carefully against the queries listed below and mark the necessary changes either directly on the proof/online grid or in the 'Author's response' area provided below

\begin{tabular}{|l|l|l|}
\hline Query & Details Required & $\begin{array}{l}\text { A u t h o r' } \\
\text { Response }\end{array}$ \\
\hline AQ1 & $\begin{array}{l}\text { Please confirm if the author names are presented accurately } \\
\text { and in the correct sequence (given name, family name). } \\
\text { Author 3 Given name: Md. Abdul, Family name: Malak; } \\
\text { Author 4 Given name: Abdul Majed, Family name: Sajib. } \\
\text { Also, kindly confirm the details in the metadata are correct. }\end{array}$ & \\
\hline AQ2 & $\begin{array}{l}\text { Kindly check and confirm the inserted city name in } \\
\text { affiliation 2 is correct and amend if necessary. }\end{array}$ & \\
\hline AQ3 & $\begin{array}{l}\text { Kindly check and confirm whether the table headers for the } \\
\text { Tables 3, 4 and 6 are correctly identified. }\end{array}$ & \\
\hline AQ4 & $\begin{array}{l}\text { Reference Bdnews24.com. (2019) was provided in the } \\
\text { reference list; however, this was not mentioned or cited } \\
\text { in the manuscript. As a rule, if a citation is present in the } \\
\text { text, then it should be present in the list. Please provide } \\
\text { the location of where to insert the reference citation in the } \\
\text { main body text. }\end{array}$ & \\
\hline AQ5 & $\begin{array}{l}\text { Kindly provide retrieved date for the references GFDRR } \\
\text { (Global Facility for Disaster Reduction and Recovery) } \\
\text { (2018), HDX (Humanitarian Data Exchange) (2020a, } \\
\text { b), Humanitarian Response (2018), Martin (2017) and } \\
\text { UNHCR Population Map.(2019). }\end{array}$ & \\
\hline AQ6 & $\begin{array}{l}\text { Kindly check and confirm the inserted volume number for } \\
\text { the reference Rashid et al. (2020) is correct and amend if } \\
\text { necessary. } \\
\text { reference Sohel (2017) is correct and amend if necessary. }\end{array}$ & \\
\hline
\end{tabular}

